\title{
REVIEW
}

\section{Air pollution, oxidative stress and dietary supplementation: a review}

\author{
I. Romieu*, F. Castro-Giner", N. Kunzli ${ }^{\#, 9}$ and J. Sunyer ${ }^{\#, 9}$
}

ABSTRACT: The aim of the present review was to provide an up-to-date overview of the biological and epidemiological evidence of the role of oxidative stress as a major underlying feature of the toxic effect of air pollutants, and the potential role of dietary supplementation in enhancing antioxidant defences.

A bibliographic search was conducted through PubMed. The keywords used in the search were “air pollutant”, “oxidative stress”, “inflammation”, “antioxidant polyunsaturated fatty acids” and "genetics". In addition, the authors also searched for biomarkers of oxidative stress and nutrients.

The review presents the most recent data on: the biological and epidemiological evidence of the oxidative stress response to air pollutants; the role of dietary supplementation as a modulator of these effects; and factors of inter-individual variation in human response. The methodology for further epidemiological studies will be discussed in order to improve the current understanding on how nutritional factors may act.

There is substantial evidence that air pollution exposure results in increased oxidative stress and that dietary supplementation may play a modulating role on the acute effect of air pollutants. Further epidemiological studies should address the impact of supplementation strategies in the prevention of air-pollution-related long-term effects in areas where people are destined to be exposed for the distant future.

KEYWORDS: Air pollution, antioxidants, nutrition, oxidative stress

pidemiological studies have clearly shown that air pollution exposure is associated with a range of respiratory and cardiovascular health effects and increased mortality [1]. Recent research has identified oxidative stress as one potential feature underlying the toxic effect of air pollutants, which trigger a number of redox sensitive signalling pathways, such as those of inflammatory response and cytokine production [2-5]. Toxicity may arise from an imbalance of biological pro-oxidant and antioxidant processes [6] linked to increased exposure to oxidants or the presence of impaired antioxidant defences [7, 8]. This imbalance has long been recognised in investigations of ozone $\left(\mathrm{O}_{3}\right)$ [9], one of the most potent oxidants, and more recent studies have focused on this particular mechanistic hypothesis [10]. Since diet is a major source of antioxidants, it is important to examine whether antioxidant defence mechanisms could be increased by dietary means to protect against air pollutants as this could have major public health consequences [11]. To provide an up-to-date overview on the biological and epidemiological evidence of the role of oxidative stress as a major underlying feature of the toxic effect of air pollutants and the potential role of dietary supplementation as an enhancer [11] of antioxidant defences, a bibliogaphic search was conducted through PubMed. The keywords used in the search were "air pollutant", "oxidative stress", "inflammation", " antioxidant" (vitamin C, vitamin E, carotenoids), "polyunsaturated fatty acids" (PUFA) and "genetics". In addition, the current authors searched for biomarkers of oxidative stress, biomarkers of antioxidant intake (selenium, flavonoids, carotenoids, vitamin C, vitamin E), and n-3 PUFA. Various recent reviews have been published on these issues [15, 7-10, 12-34], therefore, the present authors refer to these and mostly focus on the latest findings. Thus, the purpose of this up-to-date overview is five-fold. First, the relevance of oxidative stress as a common mechanism for

\section{AFFILIATIONS}

*Instituto Nacional de Salud Publica,

Cuernavaca, Mexico.

\# Instituto Municipal de

Investigaciones Médicas, and

- Institut Català de Recerca i Estudis

Avançat (ICREA), Barcelona, Spain.

CORRESPONDENCE

I. Romieu

Instituto Nacional de Salud Publica

Av. Universidad No. 655

Col. Santa Maria Ahuacatitlan

Cuernavaca

Morelos 62508

Mexico

Fax: 527773111148

E-mail: iromieu@correo.insp.mx

Received

October 022006

Accepted after revision:

August 202007

\section{SUPPORT STATEMENT}

The work was supported by the National Center for Environmental Health, Centers for Disease Control and Prevention (Atlanta, GA, USA) the $\mathrm{GA}^{2} \mathrm{LEN}$ project (EU contract F00DCT-2004-506378) and the Spanish Ministry of Education and Science (SAB2004-0192).

\section{STATEMENT OF INTEREST}

None declared. 
effects of ambient air pollutants will be summarised. Secondly, the role of antioxidants in oxidative stress will be briefly discussed. Thirdly, the evidence for dietary supplements as modulating the adverse effects due to air pollution will be reviewed. Fourthly, the relevance of factors that may interact with a subjects' response to exogenous oxidative stress will be discussed. Finally, the need to further investigate the relevance of dietary supplementation as an approach to protect from adverse effects of air pollution will be discussed.

\section{BIOLOGICAL AND EPIDEMIOLOGICAL EVIDENCE}

\section{Oxidative stress and air pollutants}

Several air pollution components have been related to particulate toxicity. An important determinant of the acute inflammatory response appears to be the dose of bio-available transition metals (such as copper, vanadium, chromium, nickel, cobalt and iron), organic compounds (such as polycyclic aromatic hydrocarbons) and biological fractions (such as endotoxins) [35, 36]. The oxidative stress mediated by particulate matter (PM) may arise from: direct generation of reactive oxygen species (ROS) from the surface of soluble compounds; altered function of mitochondria or reduced nicotinamide adenine dinucleotide phosphate (NADPH)oxidase; and activation of inflammatory cells capable of generating ROS and reactive nitrogen species (RNS), as well as oxidative DNA damage $[37,38]$. The particle provides a template for electron transfer to molecular oxygen in these reduction and oxidation (redox) cycling events [39]. In addition, target cells, such as airway epithelial cells and macrophages, generate ROS in response to particle uptake by biologically catalysed oxidation reactions that occur in the cell membrane and mitochondria [4, 40-42]. In vitro studies have shown that inhaled PM causes expression of nuclear factor

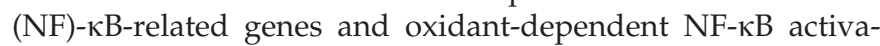
tion $[43,44]$. The dose of bio-available transition metal, rather than particulate mass, may be the primary determinant of acute inflammatory response [35, 37, 44]. However, other studies suggest that the hydrosoluble fraction is responsible for the oxidative damage to DNA [45]. The biological component of particles also seems to be related to oxidative stress [46], as well as bacterial endotoxin that induce the liberation of tumour necrosis factor (TNF)- $\alpha$ and interleukin (IL)-6 by macrophages [36].

Strong oxidative activity and the effective depletion of lung lining fluid antioxidants have been reported in large studies of ambient PM $<2.5 \mu \mathrm{m}$ (PM2.5) [17]. To defend against the oxidative damage, cells use up their stores of a key antioxidant, glutathione. The glutathione depletion can induce a state of cellular stress, which triggers an increase in the production of antioxidant enzymes through activation of a transcription factor nuclear factor-erythroid 2-related factor 2 [17]. Failure to overcome oxidative stress leads to the activation of additional intracellular signalling cascades that regulate the expression of cytokine and chemokine genes [15]. These products are produced locally in target tissues as well as systemically, and lead to widespread pro-inflammatory effects remote from the site of damage. In addition, PM appears to inhibit protective enzymes involved in oxidative stress responses depending on their toxicity (copper/zinc superoxide dismutase, manganese superoxide dismutase, glutathione peroxidase and glutathione reductase) [47].

Diesel exhaust particles (DEPs) have a high content of elemental and organic carbon and are thought to be particularly toxic [15]. These particles consist of a carbon core with adsorbed organic compounds, such as polyaromatic hydrocarbons, quinones and redox-active metals, and the capacity of DEPs to induce oxidative stress is largely related to these adsorbed components. Animal experimental models, cell culture experiments and cell free systems involving DEPs have shown oxidative stress response and oxidative DNA damage. Human studies have shown increased neutrophils, B cells and alveolar macrophages in bronchoalveolar lavage fluid and an increased amount of pro-inflammatory cytokines, chemokines and adhesion molecules [48]. Exposure to DEPs has been shown to increase airway resistance, increase IL-6 and IL- 8 in lavage fluid, increase IL- 8 mRNA expression in bronchial mucosa and upregulate endothelial adhesion molecules P-selectin and vascular cell adhesion molecule-1 [49]. ROS formed at the epithelial level after DEP exposure upregulate IL-10, promoting antigen-presenting cells and allergy to pollen [15]. However, controlled exposure to DEP in human subjects has been shown to respond with an increase in low molecular antioxidants in the alveolar compartment [50]. The role of oxidative stress in response to DEPs and other particles is further supported by in vitro studies in which ROS are generated by macrophages, neutrophils, eosiniphils and epithelial cells after stimulation by DEPs or particles [15]. Interestingly, low sulphur diesel combined with engine filters blocked a range of responses to DEPs including the oxidative stress responses in mice [51].

Alteration of autonomic functions also appears to be partly associated with oxidative stress [14]. Long-term exposure to low concentrations of PM2.5 has been shown to alter vasomotor tone, lead to vascular inflammation and potentiate atherosclerosis induced by high-fat chow in susceptible mice [52]. Although epidemiological evidence suggests that it is the fine (PM2.5) or ultrafine $(\mathrm{PM}<0.1 \mu \mathrm{m})$ fraction that contains the toxic components; the large spectrum of disease end-points (from cardiovascular to asthma attack) suggest that more than one component may be driving the health effects [2].

$\mathrm{O}_{3}$ is a very reactive gas whose uptake depends on the availability of antioxidants in the lining fluids, and its toxicity appears to be transmitted to the respiratory epithelium by secondary ROS formed by direct ozonisation of respiratory tract lining fluid lipids [16]. Alteration of the cell membrane translating an induction of lipid peroxidation and a significant modification of the redox status has been observed [53], as well as the activation of transcription factors such as NF- $\kappa B$ and increased expression of a range of pro-inflammatory cytokines and adhesion genes $[2,6] . \mathrm{O}_{3}$ has been shown to react readily with ascorbic acid, uric acid and thiols, and exposure of these molecular species to $\mathrm{O}_{3}$ results in their rapid depletion [6]. When these defence mechanisms are overwhelmed, $\mathrm{O}_{3}$ may injure the underlying cells by inducing lipid peroxidation and activating inflammatory gene expression $[6,53]$. Like $\mathrm{O}_{3}$, nitrogen dioxide $\left(\mathrm{NO}_{2}\right)$ reacts with substrates present in the lung lining fluid compartment. The oxidised species arising from the reaction between $\mathrm{NO}_{2}$ and lining fluid are responsible 
for the signalling cascade of inflammatory cells into the lung [54-56].

A hierarchical oxidative stress model has been proposed to explain the dose-dependent response to air pollutant exposure [57]. Low exposure would lead to the formation of ROS activating an antioxidant response, followed by the transcription of enzymes important in detoxification, cytoprotective and antioxidant responses. These include phase II enzymes, whose induction serves as a detoxification mechanism (e.g. $\mathrm{NAD}(\mathrm{P}) \mathrm{H}$ :quinone oxidoreductase 1 (Nqo1) and glutathione $S$ transferase). At higher exposure, the transcription NF- $\mathrm{KB}$ and activator protein-1 responses would be activated. This would lead to NF- $\mathrm{kB}$ and mitogen-activated protein kinase signalling, altering the function of mitochondria or NADPH, and to increased expression of pro-inflammatory cytokines (such as TNF- $\alpha$ and IL- 8 and IL-6) and genes coding adhesion molecules [2, 6, 15, 43, 44]. Any enhanced inflammatory response would lead to additional generation of ROS and RNS, together with oxidative DNA damage (fig. 1) [15, 37, 38].

\section{Antioxidants and oxidative stress}

Antioxidants in the lung are the first line of defence against oxygen free radicals. The respiratory tract lining fluids (RTLF) contain a range of low molecular weight antioxidants similar to

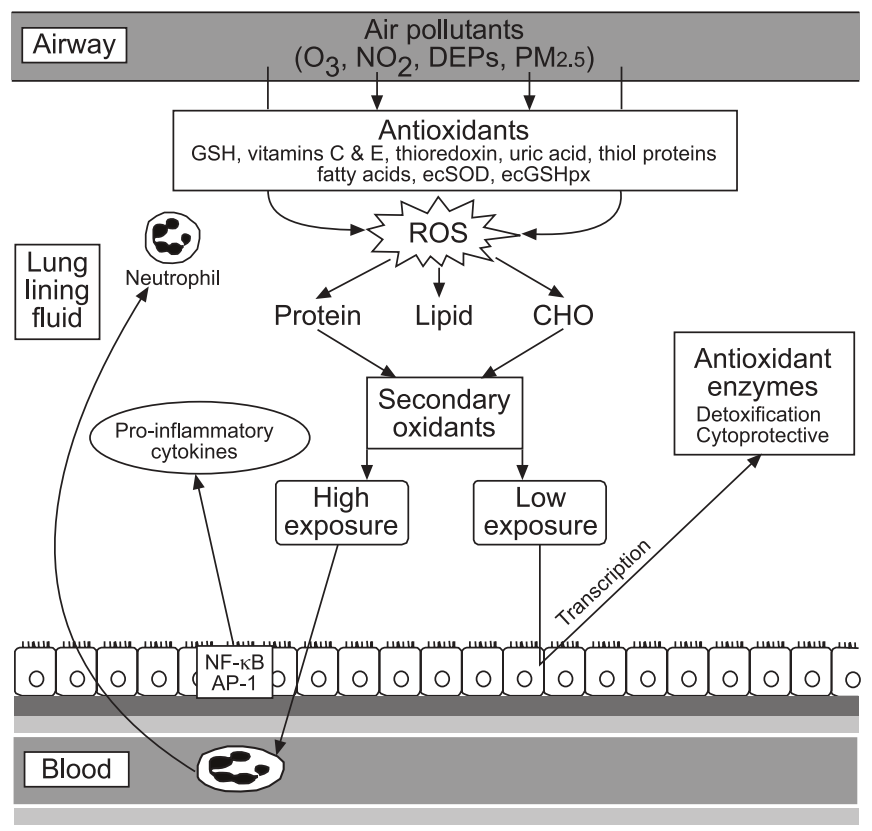

FIGURE 1. A model of the reaction of oxidants in the airway. Inhaled pollutants, such as ozone $\left(\mathrm{O}_{3}\right)$, nitrogen dioxide $\left(\mathrm{NO}_{2}\right)$, particulate matter $<2.5 \mu \mathrm{m}$ (PM2.5) or diesel exhaust particulates (DEPS), react with nonenzymatic antioxidant constituents of the respiratory tract lining fluid including: reduced glutathione (GSH); vitamin C; uric acid; and enzymatic antioxidants, such as extracellular superoxide dismutase (ecSOD), extracellular glutathione peroxidise (ecGSHpx) and thioredoxin. These molecules provide a protective screen against these pollutants. If defences are exceeded, the production of reactive oxygen species (ROS) is increased and oxidants may react with organic molecules, such as proteins or lipids, and alter the epithelium resulting in: cell activation and initiation of the inflammatory process; activation of neutrophils; and liberation of cytokines, chemokines and adhesion molecules. CHO: carbohydrate; NF-kB: nuclear factor$\kappa B$; AP-1: activator protein-1. Modified from [3]. those found in blood plasma, including reduced glutathione, ascorbic acid (vitamin $\mathrm{C}$ ), uric acid and $\alpha$-tocopherol (vitamin E). They also contain antioxidant enzymes, such as superoxide dismutase, glutathione peroxidase, thioredoxin reductase, catalase and the metal binding proteins ceruloplasmin and transferrin [2, 7]. All these antioxidants are free radical scavengers but also function as sacrificial targets for $\mathrm{O}_{3}$ (ascorbate and urate) and react rapidly with this oxidant to limit its interaction with RTLF lipids and proteins [58]. The composition and quantity of antioxidants in the RTLF may represent an important determinant of individual responsiveness to air pollutants but should be thought of as a dynamic equilibrium with the antioxidant defences within the epithelium and the more remote plasma pool [59]. Controlled studies suggest that exposure to $\mathrm{O}_{3}$ results in a depletion of RTLF antioxidants followed by an enhancement of the movement of antioxidants to the RTLF [60] or increased synthesis [3, 59]. Similarly, low-dose diesel exposure challenge in healthy volunteers was followed by an increase of inflammatory markers in bronchial lavage. No inflammatory response was seen in the alveolar compartment, but both reduced glutathione and urate concentrations were increased following diesel exposure suggesting differential antioxidant responses in the conducting airway and alveolar regions [50].

Although the inter-relation among antioxidant levels in RTLF, cellular and plasma levels is not well understood, it appears that the susceptibility of the lung to oxidative injury depends largely on its ability to upregulate protective ROS- and RNS-scavenging systems and that the speed at which lost antioxidant defences can be replaced is a major determinant [58].

As many antioxidants are derived from the diet, several dietary factors have been implicated; mainly because of their potential role in inflammatory reactions. The following section will focus mostly on nutrients that have been used in supplementation studies to modulate the impact of air pollutants or might interact with the immune response. These factors include antioxidant vitamins, omega- 3 fatty acids and other micronutrients that might affect the immune response.

\section{Antioxidant nutrients \\ Vitamin C}

Vitamin C, a water-soluble vitamin, is an abundant antioxidant substance and is widely distributed throughout the body including the extracellular lining fluid of the lung [17]. Ascorbate is an excellent reducing agent and scavenges free radical and oxidants. In vitro evidence suggests that vitamin $C$ has a role as a chemical reducing agent both intracellularly and extracellularly. Intracellular vitamin C might prevent protein oxidation and regulate gene expression and mRNA translation. This is particularly relevant for the lung which is exposed to oxidative substances. Extracellular vitamin $\mathrm{C}$ protects against oxidants and oxidant-mediated damage [61]. It contributes to antioxidant activity through scavenging a variety of free radicals and oxidants, in vitro, including superoxide radical $\left(\mathrm{O}^{2-}\right)$, peroxyl radicals, hydrogen peroxide, hypochlorous acid, singlet oxygen, oxidant air pollutants and oxidants that leak from activated neutrophils and macrophages [59, 61]. While the terminating product dehydroascorbate can be regenerated to ascorbate by intracellular enzymes, in particular thioredoxin 
reductase, which catalyses its regeneration [62], this regeneration is unlikely in the RTLF because of the lack of enzymes. Therefore, the maintenance of ascorbate level in the RTLF requires transportation from cellular sources or from the plasma pool [59]. Ascorbate also acts indirectly to prevent lipid peroxidation [59] and contributes to the regeneration of membrane-bound oxidised vitamin E [63]. Ascorbate plays a role in immune function and is transported into neutrophils and lymphocytes [18]. Whilst ascorbate has many antioxidant actions, it also has the capacity to act as a pro-oxidant in the presence of transition metals [64].

\section{Vitamin $E$}

Vitamin E, a lipid-soluble vitamin, represents the principal defence against oxidant-induced membrane injury in human tissue because of its role in breaking the lipid peroxidation chain reaction [64]. It is a potent peroxyl radical scavenger and especially protects PUFAs within the phosphsolipid biological membrane and in plasma liproteins [65]. It also decreases production of prostaglandin $\mathrm{E}_{2}$, a metabolite of arachidonic acid produced by lipid peroxidation of lung cells after $\mathrm{O}_{3}$ exposure [19]. Vitamin E appears to play a major role as an integral constituent of alveolar surfactant, whose quantity and composition conditions normal lung function [66].

\section{$\beta$-Carotene}

$\beta$-Carotene, a precursor to vitamin A and other carotenoids, accumulates in tissue membranes, scavenges $\mathrm{O}^{2-}$ and reacts directly with peroxyl free radicals generated by $\mathrm{O}_{3}$ [67]. It could, therefore, play a role in the control of inflammation and immune response through its antioxidant properties. However, recent research has shown that high-dose carotenoid supplementation may lead to both antioxidant and pro-oxidant reactions [68], depending on the redox potential of the biological environment in which it acts [69].

Other antioxidants, such as flavonoids, are scavengers of superoxide anions and peroxyl radicals [70]. In addition to antioxidant activities, flavonoids can modulate cell signalling pathways [20]. Selenium, an essential trace element that plays a role in the detoxification of peroxides and free radicals [67], could also play an important role in the prevention of lung injury [21]. As an integral part of the glutathione peroxidases and thioredoxin reductase, selenium probably interacts with every nutrient that affects the pro-oxidant/antioxidant balance of the cell. It also appears to support the activity of vitamin E in limiting lipid oxidation [71].

\section{Omega-3 PUFA}

Increased intake of omega-3 PUFA (n-3 PUFA) can decrease the inflammatory reaction by changing the contents of lipid membranes and other substrates, which are in turn the substrates for eicosanoid production [72]. The substitution of n-3 PUFA ( $\alpha$-linoleic acid; 18:3n-3 and eicosapentaenoic acid (EPA); 20:5n-3) for n-6 fatty acids (linoleic acid; 18:2n-6) in the membrane leads to the production of less potent inflammatory mediators (prostaglandin $\mathrm{E}_{3}$ instead of prostaglandin $\mathrm{E}_{2}$, and leukotriene 5 instead of leukotriene 4) [72]. Prostaglandin $E_{2}$ has been shown to act on T-lymphocytes to reduce the formation of interferon (IFN) $-\gamma$ without affecting the formation of IL-4. This may lead to the development of allergic sensitisation, since IL-4 promotes the synthesis of immunoglobulin E whereas IFN- $\gamma$ has the opposite effect [73]. Leukotriene 4 , a potent stimulator of airway smooth muscle cells, increases post-capillary vascular permeability and mediates asthma by vasoconstriction and mucus secretion. The competitive interactions between n-6 PUFA and n-3 PUFA determine the cellular contents of arachidonic acid and EPA.

Increased intake of n-3 PUFA appears to decrease the risk of sudden and nonsudden death from myocardial infarction and nonfatal myocardial infarction [74-76]. The protective effect of n-3 PUFA may be linked, in part, to its cardiac and arrhythmic effects, including increasing heart rate variability (HRV) [22, $74,77]$. There is a positive correlation between the baseline cell membrane concentrations of n-3 PUFA and the degree of HRV, both in healthy subjects and in patients with coronary artery disease [23, 78]. Along with increasing HRV, other antiarrhythmic mechanisms of n-3 PUFA have also been described, including the capacity to stabilise the electrical activity of cardiac myocytes by modulating sarcolemmal ion channels and voltage-dependent sodium channels [24], and the capacity to reduce myocardial infarct size in animal models of ischaemia and reperfusion [24]. N-3 PUFA also appear to: decrease the risk of thrombosis; decrease serum triglyceride levels, slowing the growth of atherosclerotic plaque; improve vascular endothelial function; lower blood pressure; and decrease inflammation [79].

\section{Other micronutrients and immune functions}

Micronutrients such as zinc, vitamin A and folic acid can also influence several components of immunity, altering the function of macrophages and thus their role in innate immunity and inflammation. Studies have shown that deficiencies in these micronutrients can significantly alter macrophage phagocytosis and their production of cytokines (IL-1 and IL-6, TNF- $\alpha$ and IFN- $\gamma$ ). These deficiencies also alter natural killer cell function, neutrophil motility and antimicrobial activity [25].

\section{Nutrient supplementation and effects of air pollution}

The effects on air pollutant toxicity of nutrient supplementation at levels higher than is physiologically required have been studied in both animals and humans and summarised previously $[2,11,17,80]$.

\section{Experimental animal studies}

Results of animal studies suggest that supplementation with vitamin $\mathrm{C}$ and vitamin $\mathrm{E}$ modulates the pulmonary response to exposure to photo-oxidants, such as $\mathrm{O}_{3}$ or $\mathrm{NO}_{2}[17,81]$, and that vitamin $\mathrm{C}$, uric acid and glutathione located in the respiratory tract lining fluid are consumed on exposure to $\mathrm{O}_{3}$ and $\mathrm{NO}_{2}[16,82,83]$. Dietary deficiency of vitamin $\mathrm{C}$ appears to quickly translate to decreased levels of vitamin $\mathrm{C}$ in blood and RTLF [84]. Temporary vitamin E deficiency may induce reversible changes in the expression of pro-inflammatory markers, reduce surfactant lipid synthesis in alveolar type II cells and favour the development of injury in response to air pollution insults [66]. Further experimental studies using antioxidants, iron chelators or other substances support the role of ROS as mediators of the effects of particulates [37, 54]. Oxidative stress appears to play a critical role in the activation 
of NF- $\kappa \mathrm{B}$, and cytokine-induced NF- $\kappa \mathrm{B}$ activation is prevented after treatment with antioxidants or metal chelators [54]. $\mathrm{N}$ acetylcysteine, a powerful antioxidant, had a protective effect on inflammatory response and oxidative stress damage in rats exposed to coal dust [85] and on changes in heart rate and decrease in HRV in rats exposed to urban air particles [86].

\section{Human studies}

There is little information on the impact of antioxidant supplementation on the acute effects of air pollution exposure in humans. Most existing studies have focused on the changes of acute lung function. Other outcomes included bronchial airway reactivity, inflammatory response and changes in HRV but are less numerous and consistent. All these studies were experimental studies using supplements.

\section{Antioxidant supplementation}

Lung function and airway reactivity

Early studies used experimental protocols with single pollutants and a small number of healthy adults. Levels of $\mathrm{O}_{3}$ and $\mathrm{NO}_{2}$ were very high (usually close to $1,000 \mu \mathrm{g} \cdot \mathrm{m}^{-3}$ and $>3,000 \mu \mathrm{g} \cdot \mathrm{m}^{-3}$, respectively) and subjects were supplemented for a relatively short period of time with high doses of vitamin C or vitamin E (eight to 16 times the USA recommended daily allowance of vitamin C $\left(60 \mathrm{mg} \cdot \mathrm{day}^{-1}\right)$ and vitamin E $\left(8 \mathrm{mg} \cdot\right.$ day $\left.\left.^{-1}\right)\right)[2,87-89]$. A modulating effect of antioxidant supplementation was observed in some studies of acute lung function changes [89] and airway reactivity [87] but not in others.

More recent experimental studies have addressed conditions in which the $\mathrm{O}_{3}$ level and supplement doses were lower. In a study of asthmatic adults, a cocktail of vitamin C (500 mg) and vitamin E (400 UI) protected against a decrease in peak expiratory flow from $\mathrm{SO}_{2}$ challenge after $\mathrm{O}_{3}$ exposure [90]. In another study [91], subjects were first deprived of vitamin C and then supplemented with a relatively low dose of vitamin $C$ (250 mg), vitamin E (100 mg) and vegetable cocktail. Supplementation protected against acute change in lung function (forced expiratory volume in one second and forced vital capacity) after $\mathrm{O}_{3}$ challenge. However, in well nourished individuals sensible to $\mathrm{O}_{3}$, supplementation with vitamin $\mathrm{C}$ $(500 \mathrm{mg})$ and vitamin $\mathrm{E}(100 \mathrm{mg})$ provide no protective effect on inflammatory response or lung function decrease after $\mathrm{O}_{3}$ challenge. This lack of protection was observed despite elevated plasma vitamin C (+60.1\%) and vitamin E $(+51.4 \%)$ concentrations following supplementation, and increased vitamin $\mathrm{C}$ concentrations in the airways after supplementation following $\mathrm{O}_{3}$ exposure [92].

Supplementation studies conducted in free-living populations of healthy exercising adults (the Netherlands) or adults exposed to high levels of air pollutants (Mexico) support the hypothesis that antioxidant supplementation protects against the acute effects of $\mathrm{O}_{3}$ on lung function. In these studies, healthy adults were randomised to receive vitamin $C(650 \mathrm{mg})$, vitamin $\mathrm{E}(75 \mathrm{mg})$ and $\beta$-carotene $(15 \mathrm{mg})$ for several weeks [80, 93-95]. More recently, a study of asthmatic children exposed to high levels of air pollutants in Mexico City also suggested that supplementation with vitamin $C\left(250 \mathrm{mg} \cdot\right.$ day $\left.^{-1}\right)$ and vitamin $\mathrm{E}\left(50 \mathrm{mg} \cdot \mathrm{day}^{-1}\right)$ had a modulating effect on acute lung function changes [96]. The positive effect of antioxidant supplementation was mostly found in children genetically susceptible to the effects of oxidants (glutathione $S$-transferases (GST)M1 null genotypes) [97].

\section{Inflammatory response}

Only three studies have evaluated the impact of antioxidant supplementation on airway inflammatory response to air pollutant exposure. SAMET et al. [91] observed no difference in the bronchoalveolar lavage content of polynuclear cells and other inflammatory markers between supplement and placebo groups after $\mathrm{O}_{3}$ challenge. Similarly, Mudway et al. [92] reported no effect of supplementation with vitamin $\mathrm{C}$ and vitamin $\mathrm{E}$ on $\mathrm{O}_{3}$-induced neutrophilia in healthy individuals responsive to $\mathrm{O}_{3}$. In contrast, asthmatic children heavily exposed to air pollutants and supplemented with vitamin C and vitamin E had significantly lower levels of IL-6 and IL-8 in nasal lavage than children receiving placebo [98].

\section{n-3 PUFA supplementation}

Lung function and inflammatory response

The impact of n-3 PUFA supplementation on asthmatic symptoms and exercise-induced bronchoconstriction has been examined among asthmatic subjects in various recently reviewed studies [12, 34, 99]. Most of these studies enrolled a small number of asthmatic patients randomly assigned to receive a high dose of $n-3$ PUFA (3-4 g of EPA) for a short time-period (6-10 weeks); results were inconsistent. Studies with longer intervention periods, from 6 months to $1 \mathrm{yr}$, also led to inconsistent results with some studies showing improvement in lung function [100, 101] or inflammatory markers [101-103], or no effect [104]. The dosage and duration of n-3 PUFA supplementation, and the type of asthmatic patients differed between studies and may explain the discrepancy between these studies [12, 34]. The Cochrane database of systematic reviews identified 22 studies but included only nine that fulfilled the inclusion criteria and concluded that data were insufficient to determine the effect of n-3 PUFA in asthma. None of these studies include information on air pollution.

\section{Cardiovascular effect}

Increased intake of n-3 PUFA either from dietary sources or as a pharmacological supplementation has been shown to decrease the risk of mortality from coronary heart disease [105]. In a randomised trial conducted in nursing home residents, supplementation with $2 \mathrm{~g} \cdot \mathrm{day}^{-1}$ of fish oil (each $1 \mathrm{~g}$ capsule contained $83.2 \%$ of omega- 3 fatty acids) significantly decreased the effect of PM2.5 on time and frequency domain parameters of HRV [106] This is one of two studies providing evidence that oxidant stress is one of the mechanisms explaining the effect of particle air pollution on the cardiovascular system [107]. The other study reported that statins had a mitigating effect on the HRV effects of particulate air pollution in subjects genetically susceptible to oxidative stress (lacking the GSTM1 allele) [108].

\section{Modifiers of an individual's response to oxidative stress}

Under the biological model of oxidative stress one would expect factors that modify the response to oxidative stress to also alter the effects of air pollution. Thus, nutritional status, chronic diseases and genetic factors are candidates to 
determine susceptibility to oxidative stress-related effects of air pollution [26] as all these conditions are related to poor antioxidant defence.

\section{Nutritional status}

Antioxidant vitamin supplementation provides some protection against the adverse effect of $\mathrm{O}_{3}$ on lung function in asthmatic children with slight deficiencies in these nutrients [96], and to adults depleted in vitamin C [91]. In contrast, vitamin supplementation did not protect against $\mathrm{O}_{3}$-induced lung function decrement in well nourished subjects [109].

\section{Chronic diseases}

Most chronic diseases are associated with chronic inflammation [13, 27, 28, 110-112], which might increase susceptibility to the additional oxidative stress caused by air pollution exposure. In particular, subjects with asthma [29], chronic obstructive lung diseases [113], diabetes [114] and cardiovascular diseases [115] have all been shown to have antioxidant deficiency [13] and be more susceptible to the effects of air pollution [108, 115]. As observed in the case of cigarette smoke, a significant source of oxidative stress, air pollutants would lower antioxidant defences, with deleterious health consequences [116, 117]. Evidence of the potential beneficial effect of antioxidants can be found in studies of elderly subjects in which treatment with statins [108] and n-3 PUFA supplementation [106] had a beneficial effect on response to particulate exposure.

\section{Genetic susceptibility}

As oxidative stress is an important pathway activated/ involved in the adverse effects of air pollution, the genes involved are of primary interest. Most studies have focused on single gene polymorphisms; however, it is likely that there will be a hierarchy of genes determining susceptibility, rather than one individual gene driving this process [15].

\section{GST enzymes: GSTM1, GSTP1}

GST are phase II xenobiotic metabolising enzymes that participate in the detoxification of ROS by catalysing their conjugation with glutathione [118, 119]. The common null allele of GSTM1 results in a complete lack of the enzyme and reduced or no conjugation activity [120]. It has been associated with an increase in asthma and wheezing among children exposed to environmental tobacco smoke in utero, with a decrease in lung function growth [121, 122], and also with a rapid decline in lung function in smokers [123]. In addition, polymorphic GSTM1 has been shown to act as a modifier of the lung response to fire smoke [124] and $\mathrm{O}_{3}$ [125]. Antioxidant supplementation with vitamin $\mathrm{C}$ and $\mathrm{E}$ appears to modulate the effect of $\mathrm{O}_{3}$ in asthmatic children homozygous for the GSTM1 null allele [97]. Allergen sensitive subjects with low responsive genotypes show enhanced susceptibility to the adjuvant effects of DEP [126]. A GSTM1 polymorphism has also been shown to increase sensitivity to PM, as evidenced by greater changes in HRV [108]. Moreover, glutaryl coenzyme A inhibitors, i.e. statins, with known antioxidant and antiinflammatory properties mitigate against the effects of ambient particles on HRV in subjects lacking the GSTM1 allele $[107,108]$.

\section{Other genes}

The Toll-like receptor 4 (TLR4; xr 4) gene has been implicated in innate immunity and endotoxin susceptibility [127] and has been hypothesised to play a role in $\mathrm{O}_{3}$-induced hyperpermeability [26]. TNF- $\alpha$ (Xr17) has been related to lung function changes after $\mathrm{O}_{3}$ exposure [128] and to an increased risk of asthma and wheezing that can be modified by $\mathrm{O}_{3}$ exposure [129]. TNF has been identified as a candidate gene for $\mathrm{O}_{3^{-}}$ induced airway inflammation and hyperresponsiveness [130]. Polymorphisms in TNF and lipoteichoic acid have been associated with respiratory effects of $\mathrm{O}_{3}$ in humans [128]. Arginase II has been associated with an increased risk of asthma in children, and the association appeared stronger among children with a smoking parent [131] suggesting that air pollutants could also play a role.

\section{Gene-gene interactions}

$\mathrm{O}_{3}$-induced acute effects on respiratory function have been shown to be smaller in subjects with GSTM1 null and NOQ1 Pro/Pro genotypes [132]. Similarly, a study examining asthma risk in a population highly exposed to $\mathrm{O}_{3}$ showed that the risk of asthma was significantly associated with the NOQ1 genotype in subjects with the null genotype for GSTM1 [133] Both genes have a specific function in antioxidative activities.

\section{FURTHER EPIDEMIOLOGICAL RESEARCH}

There is now substantial evidence that air pollution exposure results in increased oxidative stress, alterations in immune regulation and repeated inflammatory responses that overcome lung defences to disrupt the normal regulatory and repair processes $[10,15]$. As summarised previously, despite a plausible mechanistic model linking air pollution, oxidative stress and dietary supplementation, evidence is not sufficient. Further randomised controlled trials (RCTs) are needed in order to better understand the potential protective effect of nutrient supplementation on the effect of air pollution on respiratory and cardiovascular functions and inflammatory responses.

RCTs provide a good alternative to maximise contrast in nutrient intake for evaluating the interaction of dietary factors and air pollutants and should be conducted in both the controlled setting and in free-living populations. A controlled setting will allow assignment of air pollutant exposure and therefore, provide an accurate representation of the health effects and potential modulating effects of supplementation, while RCT conducted in free-living populations will have the advantage of representing real-life conditions.

Susceptible subjects, such as those with pre-existing respiratory or cardiac disease, micronutrient deficiency or genetic susceptibility, are the most likely to benefit from nutritional intervention (see Modifier of response section); therefore, RCTs should focus on these population subgroups. Short- and longterm effects can be studied; however, the major challenge in long-term effect studies is to assess the appropriate time-frame of exposure for the induction of the disease and, therefore, the relevant period and duration of the supplementation. There is accumulating evidence that exposure during lung development in foetal life and early childhood plays a major role, as in the case of maternal smoking [134-136]. Therefore, RCTs of pregnant females with specific risks (such as asthmatic or 
TABLE 1 Biomarkers of oxidative stress most commonly used in clinical and epidemiological studies

\begin{tabular}{|c|c|c|c|c|c|c|}
\hline $\begin{array}{l}\text { Type of } \\
\text { measurement }\end{array}$ & Biomarker & $\begin{array}{c}\text { Biological } \\
\text { sample }\end{array}$ & Laboratory technique & $\begin{array}{l}\text { Sensitivity and } \\
\text { specificity }\end{array}$ & Comments & [Ref.] \\
\hline TAC & $\begin{array}{l}\text { TRAP } \\
\text { TRAP + R-PE }\end{array}$ & $\begin{array}{l}\text { Plasma } \\
\text { Serum }\end{array}$ & Fluorescence & $\begin{array}{l}\text { Good } \\
\text { Possible artefactual } \\
\text { confounding }\end{array}$ & $\begin{array}{l}\text { Measures the cumulative action of all antioxidants } \\
\text { present in plasma and body fluids } \\
\text { TRAP: indirect measure } \\
\text { TRAP+R-PE: direct measure of peroxyl radical } \\
\text { attack on R-PE. Affected by protein } \\
\text { concentration } \\
\text { Plasma better than serum }\end{array}$ & [140-142] \\
\hline \multirow[t]{8}{*}{$\begin{array}{l}\text { Lipid } \\
\text { peroxidation }\end{array}$} & TBARS & $\begin{array}{l}\text { Tissue } \\
\text { Plasma } \\
\text { Serum }\end{array}$ & $\begin{array}{l}\text { Spectrophotometry } \\
\text { Colourimetry } \\
\text { Fluorometry }\end{array}$ & Low specificity & $\begin{array}{l}\text { Easy to use } \\
\text { Indirect measure }\end{array}$ & {$[143,144]$} \\
\hline & $\begin{array}{l}\text { MDA-TBA } \\
\text { derivatisation }\end{array}$ & $\begin{array}{l}\text { Plasma } \\
\text { Serum } \\
\text { EBC } \\
\text { Urine }\end{array}$ & $\begin{array}{l}\text { TBARS } \\
\text { HPLC/MS } \\
\text { HPLC-UV/Nis } \\
\text { HPLC with fluorescence } \\
\quad \text { detection }\end{array}$ & $\begin{array}{l}\text { Low specificity } \\
\text { Good }\end{array}$ & $\begin{array}{l}\text { Measures MDA, end product of lipoperoxidation. } \\
\text { MDA is generated mainly by arachidonic acid and } \\
\text { docosahexaenoic acid } \\
\text { With HPLC detection, MDA is not a specific } \\
\text { product of lipid peroxidation }\end{array}$ & [143-145] \\
\hline & $\begin{array}{l}\text { 4-hydroxynonenal } \\
\text { 4-hydroxy }\end{array}$ & $\begin{array}{l}\text { I Tissue } \\
\text { Blood } \\
\text { Urine }\end{array}$ & $\begin{array}{l}\text { ELISA } \\
\text { GC/MS }\end{array}$ & Good & $\begin{array}{l}\text { HNE is a toxic product of lipid peroxidation and } \\
\text { second toxic messenger of free radicals }\end{array}$ & {$[147,148]$} \\
\hline & $\begin{array}{l}\text { Hydrocarbons: } \\
\text { ethane and } \\
\text { pentane }\end{array}$ & EBC & GC & $\begin{array}{l}\text { Penthane: low } \\
\text { specificity } \\
\text { Ethane: good }\end{array}$ & $\begin{array}{l}\text { Hydrocarbons are produced through peroxidation } \\
\text { of fatty acids in cellular biomembranes, by ROS } \\
\text { Ethane: faster chromatographic measurement } \\
\text { compared with other hydrocarbons; better } \\
\text { marker for lipid peroxidation } \\
\text { Background level of pentane and isoprene in } \\
\text { human breath difficult to separate pentane from } \\
\text { isoprene by chromatography } \\
\text { Possible contamination with ambient air ethane } \\
\text { and pentane }\end{array}$ & [149-152] \\
\hline & LDL oxidation & Plasma & $\begin{array}{l}\text { Ex vivo LDL by } C D \text { assay } \\
\text { with spectrophoto- } \\
\text { metric determination }\end{array}$ & Good & $\begin{array}{l}\text { Measures the rate of } C D \text { formation } \\
\text { Cannot be known for certain whether the in vitro } \\
\text { situation accurately reflects in vivo events } \\
\text { Should reflect the antioxidant defence system. } \\
\text { Vitamin } E \text { has shown reasonably consistent } \\
\text { effects in increasing the resistance of LDL to } \\
\text { oxidation }\end{array}$ & {$[143,153-155]$} \\
\hline & & $\begin{array}{l}\text { Plasma } \\
\text { Serum }\end{array}$ & $\begin{array}{l}\text { In vivo } \\
\text { LDL-BDC with } \\
\text { spectrophotometric } \\
\text { determination }\end{array}$ & Good & $\begin{array}{l}\text { Faster and simpler to perform than the ex vivo } \\
\text { procedure } \\
\text { Measures amount baseline diene conjugation }\end{array}$ & {$[156]$} \\
\hline & Oxidised LDL & Plasma & ELISA & Poor & $\begin{array}{l}\text { These modifications may occur independently of } \\
\text { lipid peroxidation } \\
\text { Still unclear whether it can serve as a peripheral } \\
\text { marker High variability }\end{array}$ & {$[144,152,157]$} \\
\hline & $\begin{array}{l}\text { Lipid } \\
\text { hydroperoxides } \\
\text { CEOOH }\end{array}$ & Plasma & $\begin{array}{l}\text { HPLC assay with } \\
\text { chemiluminescence } \\
\text { detection }\end{array}$ & Not confirmed & $\begin{array}{l}\text { Not detectable in young healthy controls } \\
\text { Direct indicator of lipid peroxidation }\end{array}$ & {$[144,158]$} \\
\hline
\end{tabular}




\begin{tabular}{|c|c|c|c|c|c|c|}
\hline \multirow[t]{2}{*}{ Eicosanoids } & F2-isoprostane & $\begin{array}{l}\text { Plasma } \\
\text { Serum } \\
\text { Urine } \\
\text { EBC }\end{array}$ & $\begin{array}{l}\text { HPLC } \\
\text { GC/MS } \\
\text { ELISA }\end{array}$ & Good & $\begin{array}{l}\text { These markers reflect respiratory tract integrity } \\
\text { between reactive nitrogen species and ROS } \\
\text { Interaction with other prostanoids } \\
\text { Potent biological activity } \\
\text { 8-iso-PGF } \text { P }_{2 \alpha} \text { is a major component of total } F_{2} \\
\text { isoprostanes } \\
\text { In plasma, possibility of artefactual generation } \\
\text { due to arachidonic acid autoxidation } \\
\text { Better in urine - less interaction }\end{array}$ & $\begin{array}{c}{[143,144,152} \\
159,160]\end{array}$ \\
\hline & $\mathrm{PGE}_{2}$ & $\begin{array}{l}\text { EBC } \\
\text { Plasma } \\
\text { Sputum }\end{array}$ & $\begin{array}{l}\text { HPLC/MS/MS } \\
\text { ELISA } \\
\text { GC/MS }\end{array}$ & Good & Not flow dependent in healthy subjects & [159-162] \\
\hline \multirow[t]{2}{*}{$\begin{array}{l}\text { Nitrogen } \\
\text { reactive } \\
\text { species }\end{array}$} & $\begin{array}{l}\text { Nitrite: } \mathrm{NO}_{2}^{-} \\
\text {Nitrate: } \mathrm{NO}_{3}^{-}\end{array}$ & $\begin{array}{l}\text { EBC } \\
\text { Plasma }\end{array}$ & $\begin{array}{l}\text { Colourimetry } \\
\text { Fluorometry } \\
\text { lonic chromatography } \\
\text { GC/MS } \\
\text { HPLC }\end{array}$ & Good & $\begin{array}{l}\text { In healthy children, nitrite values are not related } \\
\text { to levels of exhaled NO } \\
\text { Both nitrite and nitrate quantification }\end{array}$ & {$[159,163-166]$} \\
\hline & $\begin{array}{l}\text { S-nitrosothiols } \\
\text { 3-nitrotyrosine }\end{array}$ & $\begin{array}{l}\text { Plasma } \\
\text { BAL }\end{array}$ & $\begin{array}{l}\text { Fluorometry } \\
\text { GC/MS }\end{array}$ & Good & $\begin{array}{l}\text { Formed by glutathione peroxidise; a } \\
\text { selenium-dependent enzyme }\end{array}$ & {$[159,167-169]$} \\
\hline \multirow{3}{*}{ DNA oxidation } & 8-oxodGuo & $24 \mathrm{~h}$ urine & $\begin{array}{l}\text { CG-MS } \\
\text { HPLC-ECD } \\
\text { HPLC-MS } \\
\text { Comet assay } \\
\text { ELISA }\end{array}$ & Good & $\begin{array}{l}\text { HPLC-ECD generally yields lower values } \\
\text { Enzymatic approach: FPG may detect lesions } \\
\text { other than 8-oxo-7, 8-dihydroguanine; the } \\
\text { method relies on indirect calibration } \\
\text { Reported strong correlation between overnight } \\
\text { and } 24 \text { h urinary 8-oxodGuo }{ }^{\#}\end{array}$ & {$[174,175]$} \\
\hline & $\begin{array}{l}\text { Modified comet } \\
\text { assay }\end{array}$ & DNA & SCGE & Good & $\begin{array}{l}\text { Measures DNA strand breaks } \\
\text { Proportion of DNA in the tail indicates the } \\
\text { frequency of breaks } \\
\text { Particularly sensitive to oxidative attack by } \mathrm{H}_{2} \mathrm{O}_{2}\end{array}$ & {$[143,176]$} \\
\hline & $\mathrm{HmdU}$ & $\begin{array}{l}\text { Plasma } \\
\text { Serum }\end{array}$ & ELISA & Good & $\begin{array}{l}\text { Autoantibody to oxidised DNA } \\
\text { Product of thymine oxidation }\end{array}$ & {$[143,177,178]$} \\
\hline $\begin{array}{l}\text { Protein } \\
\text { oxidation }\end{array}$ & Protein carbonyl & $\begin{array}{l}\text { Plasma } \\
\text { Lung aspirate }\end{array}$ & $\begin{array}{l}\text { Colourimetric method } \\
\text { ELISA } \\
\text { HPLC }\end{array}$ & Good & $\begin{array}{l}\text { Measures generic oxidation; does not differentiate } \\
\text { between those protein carbonyl arising directly } \\
\text { from protein oxidation and those formed by } \\
\text { adduction of other oxidised products }\end{array}$ & {$[143,153,179]$} \\
\hline
\end{tabular}




\section{TABLE 1 Continued.}

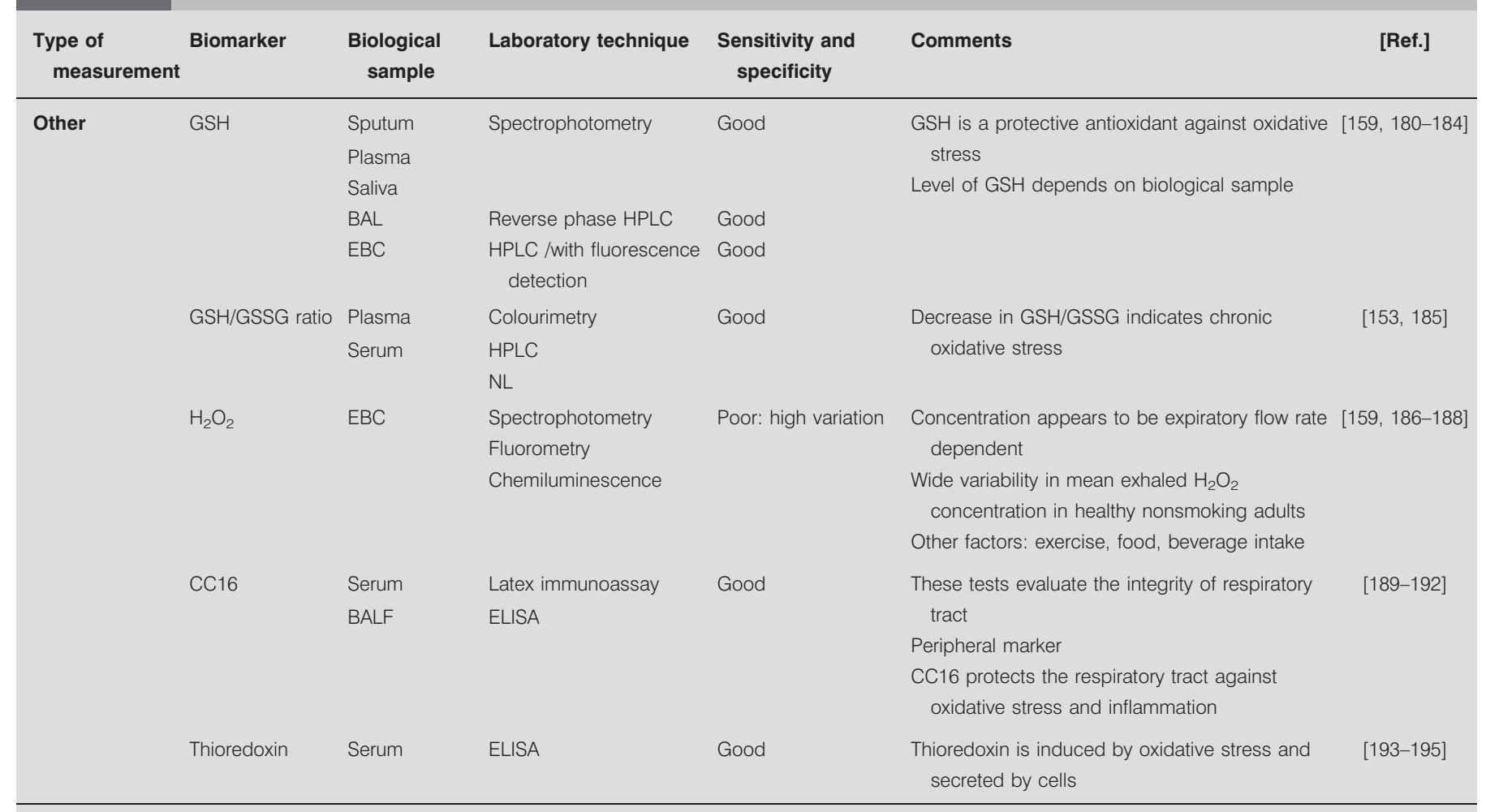

TAC: total antioxidant capacity; TRAP: total radical trapping antioxidant parameter; R-PE: R-phycoerythrin; TBARS: thiobarbituric acid-reactive substances; MDA-TBA: malondialdehyde-thiobarbituric acid; HPLC: high performance liquid chromatography; MS: mass spectometry; EBC: exhaled breath condensate; UVNis: UV/visible detection; HPCE: high performance capillary electrophoresis; HNE: 4-hydroxynonenal; GC/MS: gas chromatography/MS tandem; ROS: reactive oxygen species; CD: conjugated dienes; LDL: Iow-density lipoprotein; BDC: baseline diene conjugation; $\mathrm{CEOOH}$ : cholesteryl ester hydroperoxides; PG: prostaglandin; $\mathrm{LTB}_{4}$ : leukotriene $\mathrm{B}_{4}$ BAL: bronchoalveolar lavage; NO: nitric oxide; 8-OHdG: 8-hydroxy-2'-deoxyguanosine; ECD: electrochemical detection; 8-oxoGua: 8-oxo-7,8-dihydroguanine; FPG fasting plasma glucose; SCGE: single cell microgel electrophoresis; 8-oxodGuo: 8-oxo-7,8-dihydro-2'-deoxyguanosine; HmdU: 5-hydroxymethyl-2'-deoxyuridine; GSH reduced glutathione; GSSG: oxidised glutathione (disulfide form); NL: nasal lavage; BALF: BAL fluid(s). ${ }^{*}: r=0.93, p<0.01$

atopic mothers) might provide some insight into the role of antioxidants and n-3 PUFA as modulators of the air pollution effect. In these studies, a major challenge is the accurate assessment of air pollution exposure, oxidative stress, biomarkers of nutritional status and health outcomes. Standardisation of these factors within and between studies is crucial to allow comparability of results. In the following section some issues to be considered in future studies will be discussed.

\section{Air pollution exposure}

Contrasts in exposure need to be maximised to be able to distinguish between effects in the placebo group and smaller or no effects in the supplemented groups. Depending on the study design and hypotheses tested, either temporal or spatial contrast should be large. Multicentre studies including areas with contrasting air pollution levels and the enrolment of random samples of participants within each centre might be an option. Moreover, the design of the exposure assessment must take into account the relationship between measured or measurable markers of oxidant pollution and personal exposure to the pollutant relevant to the hypothesis. For example, there are often large indoor/outdoor ratios in $\mathrm{O}_{3}$ concentrations and these can be very heterogeneous across homes. Personal $\mathrm{O}_{3}$ concentration may be very poorly correlated with ambient levels in certain areas. It might be useful to measure the redox activity of ambient pollutants or the antioxidant depletion rates, as these may be the most relevant characteristics in the hypothesised pathways of redox imbalance. Various assays have been developed to measure the redox activity of particles, such as $\mathrm{OH}$ radical formation or antioxidant depletion rates [137]. However, the measurement methods may need further development to be applicable in epidemiological studies, in particular, for personal exposure assessment.

\section{Biomarkers of oxidative stress}

The advantage of using biomarkers is that they integrate both the effects of oxidant exposure and the full range of antioxidant protective mechanisms in vivo [30]. However, samples can be oxidised during handling, processing and analysis, so there is potential for artefacts in estimates of baseline levels of oxidation markers. The magnitude of this problem varies between biomarkers [31, 138]. Most of these biomarkers include measures of lipid, DNA and protein oxidation. Recent review articles provide broad coverage of this topic [30, 139]. Table 1 presents a summary of oxidative stress biomarkers useful for clinical and epidemiological studies including: the type of marker; the biological media for measurement; the laboratory techniques most frequently used; an appreciation of its 


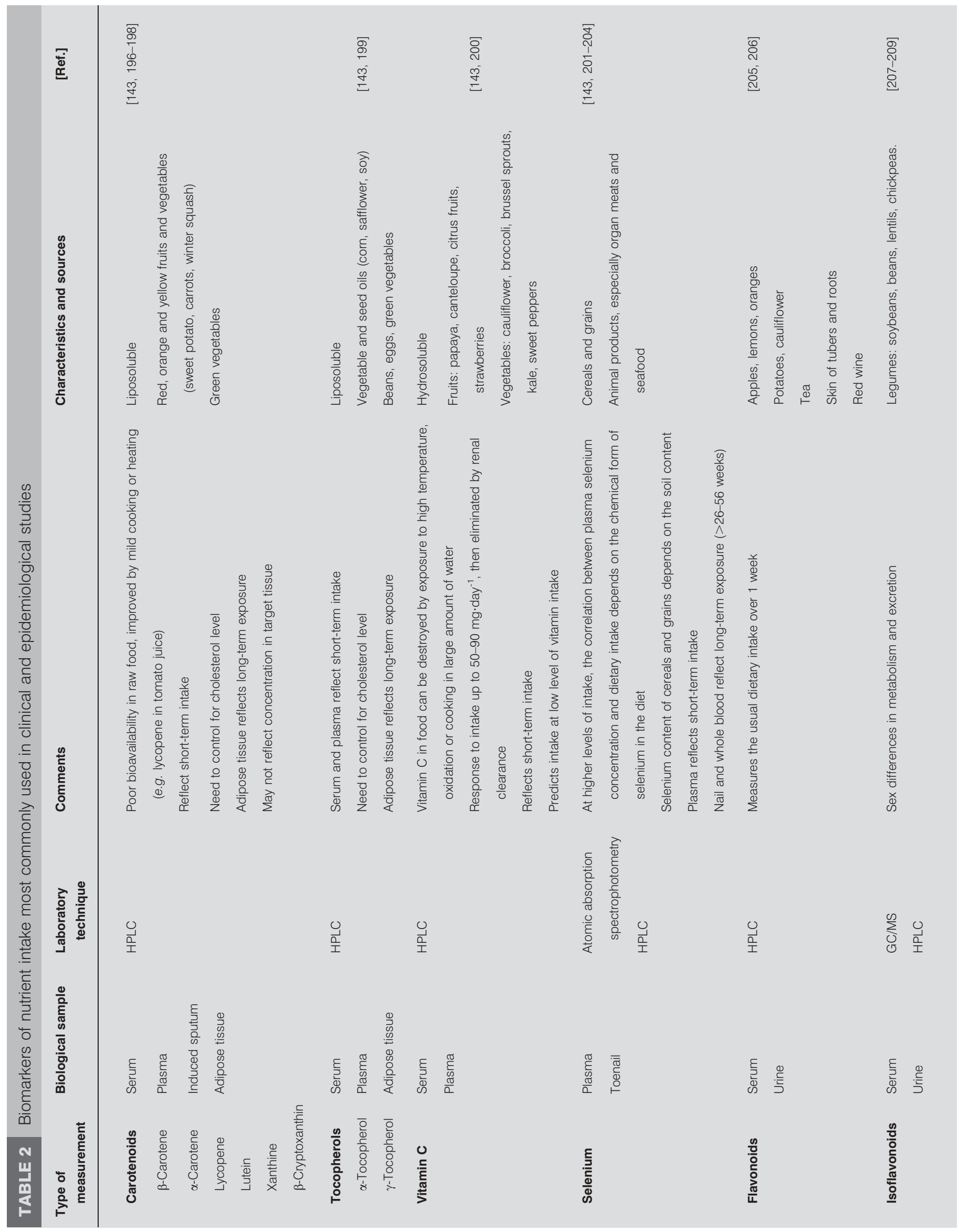




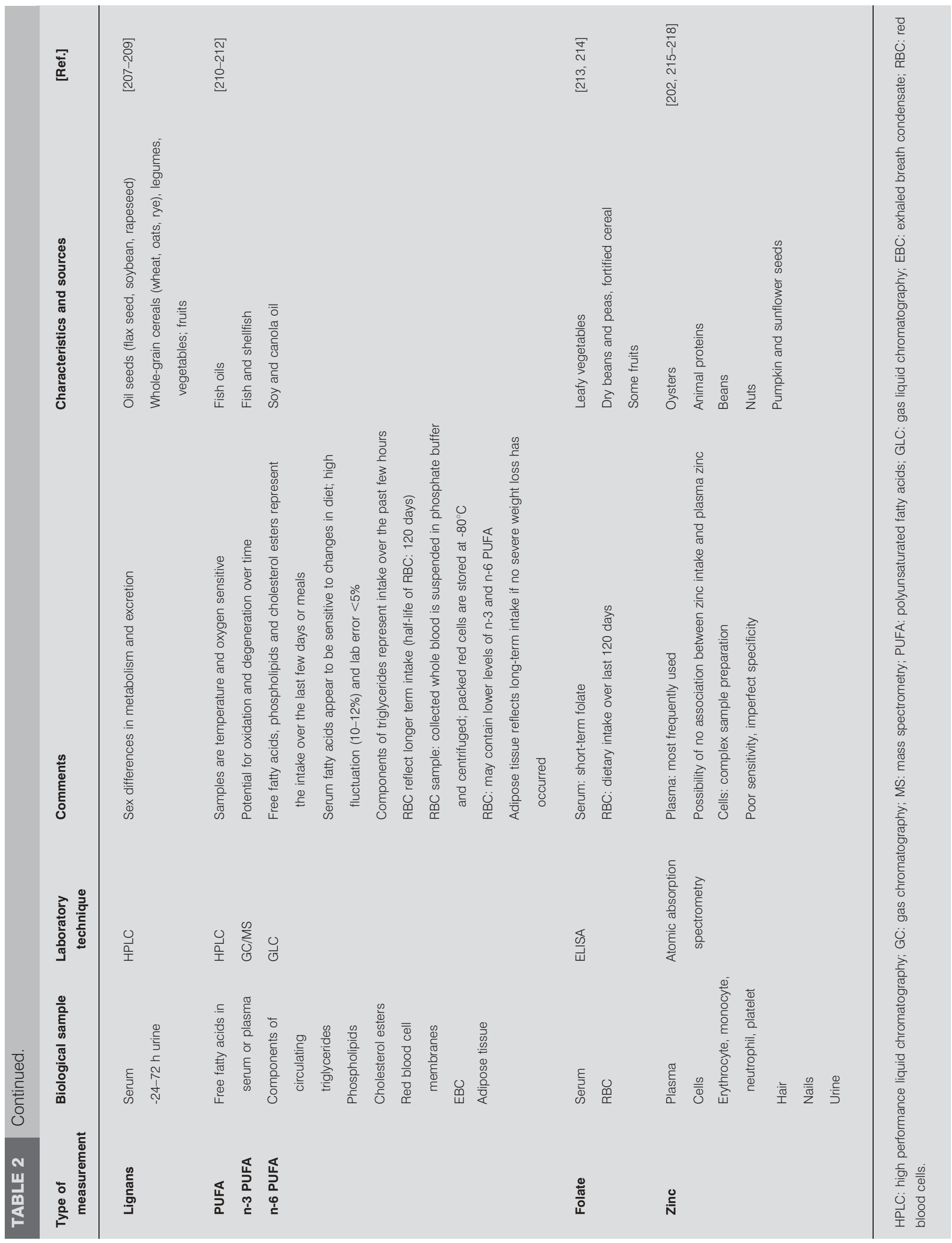


sensitivity and specificity based on the literature review; and some additional comments [140-195].

\section{Biomarkers of exposure to antioxidant nutrients and n-3PUFA}

These biochemical indicators have the advantage of integrating different food sources and providing a better estimation of the internal dose, i.e. a closer indication of the amount of nutrient available after absorption and metabolism [33]. They can also be used in intervention studies to monitor compliance with the supplement. However, they are subject to measurement errors and sampling, storage, handling and laboratory analysis and temporality issues need to be carefully considered [30]. Table 2 presents a summary of biomarkers of antioxidant and n-3 PUFA intake used in clinical and epidemiological studies including: the type of marker; the biological media for measurements; the laboratory techniques most frequently used; the characteristics and food sources of these nutrient biomarkers; and some additional comments [196-218].

\section{Health end-points}

The limited validity of symptoms of respiratory or cardiac diseases has been extensively discussed [219, 220]. Objective outcomes, such as lung function, nitric oxide in exhaled breath, carotid intimae-media thickness, electrocardiographic abnormalities or HRV, are less prone to bias and may be a good alternative but their long-term predictive value is uncertain. Biological indicators, such as pro-inflammatory markers (e.g. IL-6, IL-4, TNF- $\alpha$, IFN- $\gamma$ ) in sera, exhaled breath and nasal lavage, and peripheral inflammatory markers (e.g. cell counts, fibrinogen, C-reactive protein, von-Willebrand factor, prostaglandin E2, plasminogen activator inhibitor, cell adhesion molecules) might provide useful information about potential mechanisms of air pollutant exposure. However, they are subject to large within-person variability and limited specificity as they are common to different end-points; therefore, serial measurements over the study period are required. In addition, intra-individual variability and the temporal frame need to be considered for any of the transient end-points. A mechanistic approach that includes evaluation of several end-points at the clinical and biological levels seems most appropriate. Further understanding of the crucial role of transcription factors, DNA methylation and RNA control of gene expression will provide new perspectives on the complex interaction of air pollutants and nutritional factors.

\section{CONCLUSION}

Oxidative stress is one of the main mechanisms by which air pollutants affect respiratory and cardiovascular health. Shortterm randomised supplementation trials suggest that antioxidant vitamins and n-3 polyunsaturated fatty acids might protect against the acute effect of these pollutants, particularly in vulnerable subgroups $[80,96,106]$. However, the evidence is still limited because of the small sample size in most studies and the lack of comprehensive assessment of baseline nutritional status and oxidative stress response. Future studies should include randomised control trials of antioxidant or n-3 polyunsaturated fatty acid supplementation in susceptible populations and measure clinical, as well as intermediate, outcomes and biomarkers of oxidative stress and nutrient intake considering factors, such as reproducibility, inter- versus intra-person variability, detection limits and specificity and sensitivity of these markers. Doses and duration are still under debate but harmonisation between studies is desirable for comparison purposes.

\section{ACKNOWLEDGEMENTS}

The authors would like to thank G. Evans for reviewing the English of the manuscript.

\section{REFERENCES}

1 Brunekreef B, Holgate ST. Air pollution and health. Lancet 2002; 360: 1233-1242.

2 Kelly FJ. Oxidative stress: its role in air pollution and adverse health effects. Occup Environ Med 2003; 60: 612-616.

3 Mudway IS, Kelly FJ. Ozone and the lung: a sensitive issue. Mol Aspects Med 2000; 21: 1-48.

$4 \mathrm{Nel} \mathrm{A.} \mathrm{Atmosphere.} \mathrm{Air} \mathrm{pollution-related} \mathrm{illness:} \mathrm{effects}$ of particles. Science 2005; 308: 804-806.

5 Schlesinger RB, Kunzli N, Hidy GM, Gotschi T, Jerrett M. The health relevance of ambient particulate matter characteristics: coherence of toxicological and epidemiological inferences. Inhal Toxicol 2006; 18: 95-125.

6 Cross CE, Valacchi G, Schock B, et al. Environmental oxidant pollutant effects on biologic systems: a focus on micronutrient antioxidant-oxidant interactions. $\mathrm{Am} J$ Respir Crit Care Med 2002; 166: Suppl. 12, S44-S50.

7 Bowler RP, Crapo JD. Oxidative stress in allergic respiratory diseases. J Allergy Clin Immunol 2002; 110: 349-356.

8 Misso NL, Thompson PJ. Oxidative stress and antioxidant deficiencies in asthma: potential modification by diet. Redox Rep 2005; 10: 247-255.

9 Pryor WA. Mechanisms of radical formation from reactions of ozone with target molecules in the lung. Free Radic Biol Med 1994; 17: 451-465.

10 Gilliland FD, McConnell R, Peters J, Gong H Jr. A theoretical basis for investigating ambient air pollution and children's respiratory health. Environ Health Perspect 1999; 107: 403-407.

11 Pryor WA. Can vitamin E protect humans against the pathological effects of ozone in smog? Am J Clin Nutr 1991; 53: 702-722.

12 Woods RK, Thien FC, Abramson MJ. Dietary marine fatty acids (fish oil) for asthma in adults and children. Cochrane Database Syst Rev 2003; 2: CD001283.

13 Boots AW, Haenen GRMM, Bast A. Oxidant metabolism in chronic obstructive pulmonary disease. Eur Respir J 2003; 22: Suppl. 46, 14S-27S.

14 Brook RD, Brook JR, Rajagopalan S. Air pollution: the "Heart" of the problem. Curr Hypertens Rep 2003; 5: 32-39.

15 Saxon A, Diaz-Sanchez D. Air pollution and allergy: you are what you breathe. Nat Immunol 2005; 6: 223-226.

16 Pryor WA, Squadrito GL, Friedman M. A new mechanism for the toxicity of ozone. Toxicol Lett 1995; 82-83: 287-293.

17 Hatch GE. Asthma, inhaled oxidants, and dietary antioxidants. Am J Clin Nutr 1995; 61: Suppl. 3, 625S-630S. 
18 Bast A, Haenen GR, Doelman CJ. Oxidants and antioxidants: state of the art. Am J Med 1991; 91: Suppl. 30, S2-13S.

19 Singh U, Devaraj S, Jialal I. Vitamin E, oxidative stress, and inflammation. Annu Rev Nutr 2005; 25: 151-174.

20 Williams RJ, Spencer JP, Rice-Evans C. Flavonoids: antioxidants or signalling molecules? Free Radic Biol Med 2004; 36: 838-849.

21 Romieu I. Nutrition and lung health. Int J Tuberc Lung Dis 2005; 9: 362-374.

22 Routledge HC, Ayres JG, Townend JN. Why cardiologists should be interested in air pollution. Heart 2003; 89: 1383-1388.

23 Leaf A, Kang JX, Xiao YF, Billman GE. Clinical prevention of sudden cardiac death by $n-3$ polyunsaturated fatty acids and mechanism of prevention of arrhythmias by n3 fish oils. Circulation 2003; 107: 2646-2652.

24 Kris-Etherton PM, Harris WS, Appel LJ, American Heart Association Nutrition Committee. Fish consumption, fish oil, omega-3 fatty acids, and cardiovascular disease. Circulation 2002; 106: 2747-2757.

25 Erickson KL, Medina EA, Hubbard NE. Micronutrients and innate immunity. I Infect Dis 2000; 182: Suppl. 1, S5-S10.

26 Kleeberger SR. Genetic aspects of pulmonary responses to inhaled pollutants. Exp Toxicol Pathol 2005; 57: 147-153.

27 Oudijk E-JD, Lammers J-WJ, Koenderman L. Systemic inflammation in chronic obstructive pulmonary disease. Eur Respir J 2003; 22: Suppl. 46, S5-S13.

28 Maritim AC, Sanders RA, Watkins JB 3rd. Diabetes, oxidative stress, and antioxidants: a review. J Biochem Mol Toxicol 2003; 17: 24-38.

29 Trasande L, Thurston GD. The role of air pollution in asthma and other pediatric morbidities. J Allergy Clin Immunol 2005; 115: 689-699.

30 Mayne ST. Antioxidant nutrients and chronic disease: use of biomarkers of exposure and oxidative stress status in epidemiologic research. J Nutr 2003; 133: Suppl. 3, 933S-940S.

31 Blanck HM, Bowman BA, Cooper GR, Myers GL, Miller DT. Laboratory issues: use of nutritional biomarkers. J Nutr 2003; 133: Suppl. 3, 888S-894S.

32 Handelman GJ. High-performance liquid chromatography analysis of cholesterol linoleate hydroperoxide in oxidized low density lipoproteins: calibration by conjugated diene internal standard. Methods Enzymol 1999; 300: 43-50.

33 Potischman N. Biologic and methodologic issues for nutritional biomarkers. J Nutr 2003; 133: Suppl. 3, 875S-880S.

34 Mickleborough TD, Rundell KW. Dietary polyunsaturated fatty acids in asthma- and exercise-induced bronchoconstriction. Eur J Clin Nutr 2005; 59: 1335-1346.

35 Costa DL, Dreher KL. Bioavailable transition metals in particulate matter mediate cardiopulmonary injury in healthy and compromised animal models. Environ Health Perspect 1997; 105: 1053-1060.

36 Soukup JM, Becker S. Human alveolar macrophage responses to air pollution particulates are associated with insoluble components of coarse material, including particulate endotoxin. Toxicol Appl Pharmacol 2001; 171 20-26.

37 Gonzalez-Flecha B. Oxidant mechanisms in response to ambient air particles. Mol Aspects Med 2004; 25: 169-182.

38 Risom L, Moller P, Loft S. Oxidative stress-induced DNA damage by particulate air pollution. Mutat Res 2005; 592: 119-137.

39 Smith AD, Cowan JO, Brassett KP, Herbison GP, Taylor DR. Use of exhaled nitric oxide measurements to guide treatment in chronic asthma. N Engl J Med 2005; 35: 2163-2173.

40 Nel AE, Diaz-Sanchez D, Ng D, Hiura T, Saxon A. Enhancement of allergic inflammation by the interaction between diesel exhaust particles and the immune system. J Allergy Clin Immunol 1998; 102: 539-554.

41 Lim HB, Ichinose $\mathrm{T}$, Miyabara $\mathrm{Y}$, et al. Involvement of superoxide and nitric oxide on airway inflammation and hyperresponsiveness induced by diesel exhaust particles in mice. Free Radic Biol Med 1998; 25: 635-644.

$42 \mathrm{Li} \mathrm{N}$, Sioutas C, Cho A, et al. Ultrafine particulate pollutants induce oxidative stress and mitochondrial damage. Environ Health Perspect 2003; 111: 455-460.

43 Jimenez LA, Thompson J, Brown DA, et al. Activation of NF- $\kappa$ B by PM(10) occurs via an iron-mediated mechanism in the absence of IкB degradation. Toxicol Appl Pharmacol 2000; 166: 101-110.

44 Shukla A, Timblin C, BeruBe K, et al. Inhaled particulate matter causes expression of nuclear factor (NF)- $\mathrm{KB}-$ related genes and oxidant-dependent NF- $\mathrm{B}$ activation in vitro. Am J Respir Cell Mol Biol 2000; 23: 182-187.

45 Aganasur K, Jeff Inmon P, Dailey LA, Madden MC, Ghio AJ, Gallagher JE. Air pollution particles mediated oxidative DNA base damage in a cell free system and in human airway epithelial cells in relation to particulate metal content and bioreactivity. Chem Res Toxicol 2001; 14 879-887.

46 Squadrito GL, Cueto R, Dellinger B, Pryor WA. Quinoid redox cycling as a mechanism for sustained free radical generation by inhaled airborne particulate matter. Free Radical Biol Med 2001; 31: 1132-1138.

47 Hatzis C, Godleski JJ, Gonzalez-Flecha B, Wolfson JM, Koutrakis P. Ambient particulate matter exhibits direct inhibitory effects on oxidative stress enzymes. Environ Sci Technol 2006; 40: 2805-2811.

48 Takizawa H. Diesel exhaust particles and their effect on induced cytokine expression in human bronchial epithelial cells. Curr Opin Allergy Clin Immunol 2004; 4: 355-359.

49 Stenfors N, Nordenhall C, Salvi SS, et al. Different airway inflammatory responses in asthmatic and healthy humans exposed to diesel. Eur Respir J 2004; 23: 82-86.

50 Behndig AF, Mudway IS, Brown JL, et al. Airway antioxidant and inflammatory responses to diesel exhaust exposure in healthy humans. Eur Respir J 2006; 277: 359-365.

51 McDonald JD, Harrod KS, Seagrave J, Seilkop SK, Mauderly JL. Effects of low sulfur fuel and a catalyzed particle trap on the composition and toxicity of diesel emissions. Environ Health Perspect 2004; 112: 1307-1312.

52 Sun Q, Wang A, Jin X, et al. Long-term air pollution exposure and acceleration of atherosclerosis and vascular 
inflammation in an animal model. JAMA 2005; 294: 3003-3010.

53 Foucaud L, Bennasroune A, Klestadt D, Laval-Gilly P, Falla J. Oxidative stress induction by short time exposure to ozone on THP-1 cells. Toxicol In Vitro 2006; 20: 101-108.

54 Janssen-Heininger YMW, Persinger RL, Korn SH, et al. Reactive nitrogen species and cell signaling. Implications for death or survival of lung epithelium. Am J Respir Crit Care Med 2002; 166: Suppl. 12, S9-S16.

55 Kelly FJ, Tetley TD. Nitrogen dioxide depletes uric acid and ascorbic acid but not glutathione from lung lining fluid. Biochem J 1997; 325: 95-99.

56 Persinger RL, Poynter ME, Ckless K, JanssenHeininger YM. Molecular mechanisms of nitrogen dioxide induced epithelial injury in the lung. Mol Cell Biochem 2002; 234-235: 71-80.

57 Xiao GG, Wang M, Li N, Loo JA, Nel AE. Use of proteomics to demonstrate a hierarchical oxidative stress response to diesel exhaust particle chemicals in a macrophage cell line. J Biol Chem 2003; 278: 50781-50790.

58 Kelly FJ. Dietary antioxidants and environmental stress. Procc Nutr Soc 2004; 63: 579-585.

59 Kelly FJ, Mudway IS. Protein oxidation at the air-lung interface. Amino Acids 2003; 25: 375-396.

60 Freed AN, Cueto R, Pryor WA. Antioxidant transport modulates peripheral airway reactivity and inflammation during ozone exposure. J Appl Physiol 1999; 87: 7595-7603.

61 Levine M, Katz A, Padayatt SJ. Vitamin C. In: Shils M, Shike M, Ross AC, et al., eds. Modern Nutrition in Health and Disease. Philadelphia, Lippincott Williams \& Willkins, 2006; pp. 507-524.

62 Mustacich D, Powis G. Thioredoxin reductase. Biochem J 2000; 346: 1-8.

63 McCay PB. Vitamin E: interaction with free radicals and ascorbate. Ann Rev Nutr 1985; 5: 323-340.

64 Burton GW, Ingold KU. Autooxidation of biological molecules. 1. The antioxidant activity of vitamin E and related chain-breaking phenolic antioxidants in vitro. J Am Chem Soc 1981; 103: 6472-6477.

65 Traber MG. Vitamin E. In: Shils ME, Shike M, Ross AC, et al., eds. Modern Nutrition in Health and Disease. Philadelphia, Lipincott Williams \& Wilkins, 2006; pp. 396-311.

66 Kolleck I, Sinha P, Rustow B. Vitamin E as an antioxidant of the lung: mechanisms of vitamin E delivery to alveolar type II cells. Am J Respir Crit Care Med 2002; 166: S62-S66.

67 Linder MC. Nutrition and metabolism of trace elements. In: Linder MC, ed. Nutrition Biochemistry and Metabolism with Clinical Application. Norwalk, Appleton and Lange, 1991; pp. 213-276.

68 Siems W, Wiswedel I, Salerno C, et al. $\beta$-Carotene breakdown products may impair mitochondrial functions-potential side effects of high-dose $\beta$-carotene supplementation. J Nutr Biochem 2005; 16: 385-397.

69 Palozza P, Serini S, Di Nicuolo F, Piccioni E, Calviello G. Prooxidant effects of $\beta$-carotene in cultured cells. Mol Aspects Med 2003; 24: 353-362.

70 Sies H, ed. Oxidative Stress: Oxidants and Antioxidants. San Diego, Academic Press, 1991.

71 Burk RF, Levander OA. Selenium. In: Shils M, Olson JA, Shike M, Ross AC, eds. Modern Nutrition in Health and
Disease. Baltimore, Williams, \& Wilkins, 1999; pp. 265-276.

72 Schwartz J, Weiss ST. Dietary factors and their relation to respiratory symptoms. Am J Epidemiol 1990; 132: 67-76.

73 Rossi AG, Haslett C. Inflammation, cell injury, and apoptosis. In: Sais SE, ed. Proinflammatory and Antiinflammatory Peptides. New York, Marcel Dekker, 1998.

74 Holguin F, Tellez-Rojo MM, Hernandez M, et al. Air pollution and heart rate variability among the elderly in Mexico City. Epidemiology 2003; 14: 521-527.

75 Gold DR, Litonjua A, Schwartz J, et al. Ambient pollution and heart rate variability. Circulation 2000; 101: 1267-1273.

76 Zipes DP, Wellens HJ. Sudden cardiac death. Circulation 1998; 98: 2334-2351.

77 Godleski JJ, Verrier RL, Koutrakis P, et al. Mechanisms of morbidity and mortality from exposure to ambient air particles. Res Rep Health Eff Inst 2000:5-88.

78 Katan MB, Deslypere JP, Van Birgelen AP, Pernders M, Zegwaard M. Kinetic of the incorporation of dietary fatty acids into serum cholesterly esters, erythrocyte membranes, and adipose tissue: an 18-month controlled study. J Lipid Res 1997; 38: 2012-2022.

79 Kris-Etherton PM, Harris WS, Appel LJ, American Heart Association Nutrition Committee. Omega-3 fatty acids and cardiovascular disease: new recommendations from the American Heart Association. Arterioscler Thromb Vasc Biol 2003; 23: 151-152.

80 Grievink L, Smit HA, Brunekreef B. Anti-oxidants and air pollution in relation to indicators of asthma and COPD: a review of the current evidence. Clin Exp Allergy 2000; 30: 1344-1354.

81 Elsayed NM. Antioxidant mobilization in response to oxidative stress: a dynamic environmental-nutritional interaction. Nutrition 2001; 17: 828-834.

82 Menzel DB. The toxicity of air pollution in experimental animals and humans: the role of oxidative stress. Toxicol Lett 1994; 72: 269-277.

83 Menzel DB. Antioxidants in lung disease. Toxicol Ind Health 1993; 9: 323-336.

84 Dunster C, Kelly FJ. Dietary modulation of lung epithelial lining fluid vitamin C concentration. Respir Med 1994; 88: 815.

85 Pinho RA, Silveira PC, Silva LA, Luiz Streck E, DalPizzol F, Moreira JC. N-acetylcysteine and deferoxamine reduce pulmonary oxidative stress and inflammation in rats after coal dust exposure. Environ Res 2005; 99: 355-360.

86 Rhoden CR, Wellenius GA, Ghelfi E, Lawrence J, Gonzalez-Flecha B. PM-induced cardiac oxidative stress and dysfunction are mediated by autonomic stimulation. Biochim Biophys Acta 2005; 1725: 305-313.

87 Mohsenin V. Effect of vitamin $\mathrm{C}$ on $\mathrm{NO}_{2}$-induced airway hyperresponsiveness in normal subjects. A randomized double-blind experiment. Am Rev Respir Dis 1987; 136: 1408-1411.

88 Chatham MD, Eppler Jr JH, Sauder LR, Green D, Kulle TJ. Evaluation of the effects of vitamin $\mathrm{C}$ on ozone-induced bronchoconstriction in normal subjects. Ann N Y Acad Sci 1987; 498: 269-279.

89 Hackney JD, Linn WS, Buckley RD, et al. Vitamin E supplementation and respiratory effects of ozone in humans. J Toxicol Environ Health 1981; 7: 383-390. 
90 Trenga CA, Williams PV, Koenig JQ. Dietary antioxidants attenuate ozone-induced bronchial hyperresponsiveness (BHR) in asthmatic adults. Am J Resp Crit Care Med 1997; 155: A732.

91 Samet JM, Hatch GE, Horstman D, et al. Effect of antioxidant supplementation on ozone-induced lung injury in human subjects. Am J Respir Crit Care Med 2001; 164: 819-825.

92 Mudway IS, Behndig AF, Helleday R, et al. Vitamin supplementation does not protect against symptoms in ozone-responsive subjects. Free Radic Biol Med 2006; 40: 1702-1712.

93 Grievink L, Zijlstra AG, Ke X, Brunekreef B. Acute effects of ozone on pulmonary function in antioxidant supplemented cyclists. Eur Resp J 1997; 10: Suppl. 25, 229 S.

94 Grievink L, Zijlstra AG, Ke X, Brunekreef B. Double-blind intervention trial on modulation of ozone effects on pulmonary function by antioxidant supplements. Am J Epidemiol 1999; 149: 306-314.

95 Romieu I, Meneses F, Ramirez M, et al. Antioxidants supplementation and respiratory functions among workers exposed to high levels of ozone. Am J Resp Crit Care Med 1998; 158: 226-232.

96 Romieu I, Sienra-Monge JJ, Ramirez-Aguilar M, et al. Antioxidants supplementation and lung function among asthmatic children exposed to high levels of air pollutants. Am J Respir Crit Care Med 2002; 166: 703-709.

97 Romieu I, Sienra-Monge JJ, Ramirez-Aguilar M, et al. Genetic polymorphism of GSTM1 and antioxidant supplementation influence lung function in relation to ozone exposure in asthmatic children in Mexico City. Thorax 2004; 59: 8-10.

98 Sienra-Monge JJ, Ramirez-Aguilar M, Moreno-Macias H, et al. Antioxidant supplementation and nasal inflammatory responses among young asthmatics exposed to high levels of ozone. Clin Exp Immunol 2004; 138: 317-322.

99 Mickleborough TD. Dietary omega-3 polyunsaturated fatty acid supplementation and airway hyperresponsivenes in asthma. J Asthma 2005; 42: 305-314.

100 Dry J, Vincent D. Effect of a fish oil diet on asthma: results of a 1-year double-blind study. Int Arch Allergy Appl Immunol 1991; 95: 156-157.

101 Mickleborough TD, Murray RL, Ionescu AA, Lindley MR. Fish oil supplementation reduces severity of exerciseinduced bronchoconstriction in elite athletes. Am J Respir Crit Care Med 2003; 168: 1181-1189.

102 Hodge L, Salome CM, Hughes JM, et al. Effect of dietary intake of omega-3 and omega- 6 fatty acids on severity of asthma in children. Eur Resp J 1998; 11: 361-365.

103 Arm JP, Horton CE, Spur BW, Mencia-Huerta JM, Lee TH. The effects of dietary supplementation with fish oil lipids on the airways response to inhaled allergen in bronchial asthma. Am Rev Respir Dis 1989; 139: 1395-1300.

104 Thien FC, Mencia-Huerta JM, Lee TH. Dietary fish oil effects on seasonal hay fever and asthma in pollensensitive subjects. Am Rev Respir Dis 1993; 147: 1138-1143.

105 Marchioli R, Barzi F, Bomba E, et al. Early protection against sudden death by $n-3$ polyunsaturated fatty acids after myocardial infarction: time-course analysis of the results of the Gruppo Italiano per lo Studio della
Sopravvivenza nell'Infarto Miocardico (GISSI)Prevenzione. Circulation 2002; 105: 1897-1903.

106 Romieu I, Tellez-Rojo MM, Lazo M, et al. Omega-3 fatty acid prevents heart rate variability reductions associated with particulate matter. Am J Respir Crit Care Med 2005; 172: 1534-1540.

107 Wayne EC. Cardiopulmonary health effects of air pollution: is a mechanism emerging? Am J Respir Crit Care Med 2005; 172: 1482-1484.

108 Schwartz J, Park SK, O'Neill MS, et al. Glutathione-Stransferase M1, obesity, statins, and autonomic effects of particles: gene-by-drug-by-environment interaction. Am J Respir Crit Care Med 2005; 172: 1529-1533.

109 Mudway I, Blomberg A, Helleday R, Frew A, Sandstrom T, Kelly FJ. Supplementation with vitamin C does not influence lung function in healthy subjects. Eur Respir J 2000; 16: Suppl. 31, $116 \mathrm{~S}$.

110 Paredi P, Kharitonov SA, Barnes PJ. Analysis of expired air for oxidation products. Am J Respir Crit Care Med 2002; 166: Suppl. 12, S31-S37.

111 Ratnawati R, Thomas PS. Exhaled nitric oxide in paediatric asthma. Chron Respir Dis 2005; 2: 163-174.

112 Uchida K. Role of reactive aldehyde in cardiovascular diseases. Free Radic Biol Med 2000; 28: 1685-1696.

113 Mannino DM. Epidemiology and global impact of chronic obstructive pulmonary disease. Semin Respir Crit Care Med 2005; 26: 204-210.

114 O'Neill MS, Veves A, Zanobetti A, et al. Diabetes enhances vulnerability to particulate air pollution-associated impairment in vascular reactivity and endothelial function. Circulation 2005; 111: 2913-2920.

115 Bateson TF, Schwartz J. Who is sensitive to the effects of particulate air pollution on mortality? A case-crossover analysis of effect modifiers. Epidemiology 2004; 15: 143-149.

116 Alberg A. The influence of cigarette smoking on circulating concentrations of antioxidant micronutrients. Toxicology 2002; 180: 121-137.

117 Dietrich M, Block G, Norkus EP, et al. Smoking and exposure to environmental tobacco smoke decrease some plasma antioxidants and increase $\gamma$-tocopherol in vivo after adjustment for dietary antioxidant intakes. Am J Clin Nutr 2003; 77: 160-166.

118 Hayes JD, Strange RC. Glutathione S-transferase polymorphism and their biological consequences. Pharmacology 2000; 61: 154-166.

119 Rushmore TH, Pickette CB. Glutathione S-transferase, structure, regulation, and therapeutic implications. J Biol Chemist 1993; 268: 11475-11478.

120 Rebbeck TR. Molecular epidemiology of the human glutathione S-transferase genotype GSTM1 and GSTT1 in cancer susceptibiltity. Cancer Epidemiol Biom Prev 1997; 6: 733-743.

121 Gilliland FD, Lin Y, Dubeau L, et al. Effects of glutatione $S$-transferase M1, maternal smoking during pregnancy and environmental tobacco smoke on asthma and wheezing in children. Am J Respir Crit Care Med 2002; 166: 457-463.

122 Gilliland FD, Guaderman J, Vora H, Rappaport E, Dubeau L. Effects of glutathione S-transferase M1, T1, and P1 on childhood lung function growth. Am J Respir Crit Care Med 2002; 166: 710-716. 
123 He JQ, Ruan J, Connett JE, Anthonisen NR, Paré PD, Sandford AJ. Anitoxidant gene polymorphisms and susceptibility to a rapid decline in lung function in smokers. Am J Respir Crit Care Med 2002; 166: 323-328.

124 Kunzli N, Avol E, Gauderman J, et al. GSTM1 status modifies the effects of wildfire smoke on asthma symptoms. International Conference of the American Thoracic Society. Am J Respir Crit Care Med 2006: A502.

125 Corradi M, Alinovi R, Goldoni M, et al. Biomarkers of oxidative stress after controlled human exposure to ozone. Toxicol Lett 2002; 134: 219-225.

126 Gilliland FD, Li YF, Saxon A, Diaz-Sanchez D. Effect of glutathione-S-transferase M1 and P1 genotypes on xenobiotic enhancement of allergic responses: randomised, placebo-controlled crossover study. Lancet 2004; 363: 119-125.

127 Kopp EB, Medzhitov R. The Toll-receptor family and control of innate immunity. Curr Opin Immunol 1999; 11: 13-18.

128 Yang IA, Holz O, Jorres RA, et al. Association of tumor necrosis factor- $\alpha$ polymorphisms and ozone-induced change in lung function. Am J Respir Crit Care Med 2005; 171: 171-176.

129 Bayley JP, Ottenhoff TH, Verweij CL. Is there a future for TNF promoter polymorphisms? Genes Immun 2004; 5: 315-329.

130 Kleeberger SR, Levitt RC, Zhang LY, et al. Linkage analysis of susceptibility to ozone-induced lung inflammation in inbred mice. Nat Genet 1997; 17: 475-478.

$131 \mathrm{Li} \mathrm{H}$, Romieu I, Sienra-Monge JJ, et al. Genetic polymorphisms in arginase I and II and childhood asthma and atopy. J Allergy Clin Immunol 2006; 117: 119-126.

132 Bergamaschi E, De Palma G, Mozzoni P, et al. Polymorphism of quinone-metabolizing enzymes and susceptibility to ozone-induced acute effects. Am J Respir Crit Care Med 2001; 163: 1426-1431.

133 David GL, Romieu I, Sienra-Monge JJ, et al. Nicotinamide adenine dinucleotide (phosphate) reduced:quinone oxidoreductase and glutathione $S$-transferase M1 polymorphisms and childhood asthma. Am J Respir Crit Care Med 2003; 168: 1199-1104.

134 Tager IB, Weiss ST, Muñoz A, Rosner B, Speizer FE. Longitudinal study of the effects of maternal smoking on pulmonary function in children. N Engl J Med 1983; 309: 699-603.

135 Hanrahan JP, Tager IB, Segal MR, et al. The effect of maternal smoking during pregnancy on early infant lung function. Am Rev Respir Dis 1992; 145: 1129-1135.

136 Paige RC, Royce FH, Plopper CG, Buckpitt AR. Longterm exposure to ozone increases acute pulmonary centriacinar injury by 1-nitronaphthalene: I. Regionspecific enzyme activity. J Pharmacol Exp Ther 2000; 295: 934-941.

137 Künzli N, Götschi T, Mudway IS, et al. Comparison of oxidative properties, light absorbance, total and elemental mass concentration of ambient PM2.5 collected at 20 European sites. Environ Health Perspect 2006; 114: 684-690.

138 Cadet J, Douki T, Ravanat JL. Artifacts associated with the measurement of oxidized DNA bases. Environ Health Perspect 1997; 105: 1034-1039.
139 Handelman GJ, Pryor WA. Evaluation of antioxidant status in humans. In: Papas AM, ed. Antioxidant status, diet, nutrition and health. Florida, CRC Press, Boca Raton, 1999; pp. 37-62.

140 Ghiselli A, Serafini M, Natella F, Scaccini C. Total antioxidant capacity as a tool to assess redox status: critical view and experimental data. Free Radic Biol Med 2000; 30: 1036-1044.

141 Huang D, Ou B, Prior RL. The chemistry behind antioxidant capacity assays. J Agric Food Chem 2005; 53: 1841-1856.

142 Wayner DD, Burton GW, Ingold KU, Locke S. Quantitative measurement of the total, peroxyl radicaltrapping antioxidant capability of human blood plasma by controlled peroxidation. The important contribution made by plasma proteins. FEBS Lett 1985; 187: 33-37.

143 Mayne ST. Antioxidant nutrients and chronic disease: use of biomarkers of exposure and oxidative stress status in epidemiologic research. J Nutr 2003; 133: Suppl. 3, 933S-940S.

144 Cherubini A, Ruggiero C, Polidori MC, Mecocci P. Potential markers of oxidative stress in stroke. Free Radic Biol Med 2005; 39: 841-852.

145 Del Rio D, Stewart AJ, Pellegrini N. A review of recent studies on malondialdehyde as toxic molecule and biological marker of oxidative stress. Nutr Metab Cardiovasc Dis 2005; 15: 316-328.

146 Karatas F, Karatepe M, Baysar A. Determination of free malondialdehyde in human serum by high-performance liquid chromatography. Anal Biochem 2002; 311: 76-79.

147 Zarkovic N. 4-hydroxynonenal as a bioactive marker of pathophysiological processes. Mol Aspects Med 2003; 24: 281-291.

148 Gueraud F, Peiro G, Bernard H, et al. Enzyme immunoassay for a urinary metabolite of 4-hydroxynonenal as a marker of lipid peroxidation. Free Radic Biol Med 2006; 40: 54-62.

149 Paredi P, Kharitonov SA, Barnes PJ. Elevation of exhaled ethane concentration in asthma. Am J Respir Crit Care Med 2000; 162: 1450-1454.

150 Meagher EA, FitzGerald GA. Indices of lipid peroxidation in vivo: strengths and limitations. Free Radic Biol Med 2000; 28: 1745-1750.

151 Kanoh S, Kobayashi H, Motoyoshi K. Exhaled ethane: an in vivo biomarker of lipid peroxidation in interstitial lung diseases. Chest 2005; 128: 2387-2392.

152 Wood LG, Gibson PG, Garg ML. Biomarkers of lipid peroxidation, airway inflammation and asthma. Eur Respir J 2003; 21: 177-186.

153 Griffiths HR, Moller L, Bartosz G, et al. Biomarkers. Mol Aspects Med 2002; 23: 101-208.

154 Puhl H, Waeg G, Esterbauer H. Methods to determine oxidation of low-density lipoproteins. Methods Enzymol 1994; 233: 425-441.

155 Cole TG, Parikh N. High-throughput measurement of oxidizability of low-density lipoproteins suitable for use in clinical trials. Clin Chem 1999; 45: 696-699.

156 Ahotupa M, Asankari TJ. Baseline diene conjugation in LDL lipids: an indicator of circulating oxidized LDL. Free Radic Biol Med 1999; 27: 1141-1150. 
157 Uno M, Kitazato KT, Nishi K, Itabe H, Nagahiro S. Raised plasma oxidised LDL in acute cerebral infarction. J Neurol Neurosurg Psychiatry 2003; 74: 312-316.

158 Polidori MC, Frei B, Cherubini A, et al. Increased plasma levels of lipid hydroperoxides in patients with ischemic stroke. Free Radic Biol Med 1998; 25: 561-567.

159 Rosias P, Robroeks C, Hendriks J, Dompeling E, Jobsis Q. Exhaled breath condensate: a space odessey, where no one has gone before. Eur Respir J 2004; 24: 189-190.

160 Montuschi P, Barnes PJ. Exhaled leukotrienes and prostaglandins in asthma. J Allergy Clin Immunol 2002; 109: 615-620.

161 Montuschi P, Ragazzoni E, Valente S, et al. Validation of eicosanoid measurements in exhaled breath condensate. Eur Respir J 2002; 20: Suppl. 38, 422s-423s.

162 Montuschi P, Ragazzoni E, Valente S, et al. Validation of 8-isoprostane and prostaglandin $\mathrm{E}(2)$ measurements in exhaled breath condensate. Inflamm Res 2003; 52: 502-507.

163 Latzin P, Griese M. Exhaled hydrogen peroxide, nitrite and nitric oxide in healthy children: decrease of hydrogen peroxide by atmospheric nitric oxide. Eur J Med Res 2002; 7: 353-358.

164 Tsikas D. Simultaneous derivatization and quantification of the nitric oxide metabolites nitrite and nitrate in biological fluids by gas chromatography/mass spectrometry. Anal Chem 2000; 72: 4046-4072.

165 Corradi M, Folesani G, Andreoli R, et al. Aldehydes and glutathione in exhaled breath condensate of children with asthma exacerbation. Am J Respir Crit Care Med 2003; 167: 395-399.

166 Dziedzic B, Mazanowska-Gajdowicz J, Walczewska A, Nowak D. Application of Griess method for $\mathrm{NO}_{2}^{-} / \mathrm{NO}_{3}{ }^{-}$ measurement in expired breath condensate. Eur Respir J 2002; 20: Suppl. 38, 92s.

167 Hensley K, Williamson KS, Floyd RA. Measurement of 3nitrotyrosine and 5-nitro- $\gamma$-tocopherol by high-performance liquid chromatography with electrochemical detection. Free Radic Biol Med 2000; 28: 520-528.

168 Wink DA, Kim S, Coffin D, et al. Detection of $S$ nitrosothiols by fluorometric and colorimetric methods. Methods Enzymol 1999; 301: 201-211.

169 Larstad M, Soderling AS, Olin AC, Caidahl K, Toren K. Mass-selective determination of free 3-nitrotyrosine in breath condensate. Eur Respir J 2002; 20: Suppl. 31, 484s.

170 Halliwell B. Why and how should we measure oxidative DNA damage in nutritional studies? How far have we come? Am J Clin Nutr 2000 Nov, 72: 1082-1087.

171 Santella RM. Immunological methods for detection of carcinogen-DNA damage in humans. Cancer Epidemiol Biomarkers Prev 1999; 8: 733-739.

172 Long L, McCabe DR, Dolan ME. Determination of 8oxoguanine in human plasma and urine by highperformance liquid chromatography with electrochemical detection. J Chromatogr B Biomed Sci Appl 1999; 731: 241-249.

173 Sauvaigo S, Petec-Calin C, Caillat S, Odin F, Cadet J. Comet assay coupled to repair enzymes for the detection of oxidative damage to DNA induced by low doses of $\gamma$ radiation: use of YOYO-1, low-background slides, and optimized electrophoresis conditions. Anal Biochem 2002; 303: 107-109.
174 Collins AR. Assays for oxidative stress and antioxidant status: applications to research into the biological effectiveness of polyphenols. Am J Clin Nutr 2005; 81: Suppl. 1, 261S-267S.

175 Gedik CM, Boyle SP, Wood SG, Vaughan NJ, Collins AR. Oxidative stress in humans: validation of biomarkers of DNA damage. Carcinogenesis 2002; 23: 1441-1446.

176 Collins AR, Duthie SJ, Dobson VL. Direct enzymic detection of endogenous oxidative base damage in human lymphocyte DNA. Carcinogenesis. 1993; 14: 1733-1735.

$177 \mathrm{Hu}$ JJ, Chi CX, Frenkel K, et al. $\alpha$-Tocopherol dietary supplement decreases titers of antibody against 5hydroxymethyl-2'-deoxyuridine (HMdU). Cancer Epidemiol Biomarkers Prev 1999; 8: 693-698.

178 Frenkel K, Karkoszka J, Glassman T, et al. Serum autoantibodies recognizing 5-hydroxymethyl-2'-deoxyuridine, an oxidized DNA base, as biomarkers of cancer risk in women. Cancer Epidemiol Biomarkers Prev. 1998; 7: 49-57.

179 Buss H, Chan TP, Sluis KB, Domigan NM, Winterbourn CC. Protein carbonyl measurement by a sensitive ELISA method. Free Radic Biol Med 1997; 23: 361-366.

180 Corradi M, Saglia S, Majori M, Zanini A, Pesci A, Cuomo A. A new technique for measurement of nitrate in breath condensate. Am J Respir Crit Care Med 2000; 161: A395.

181 Beeh KM, Beier J, Haas IC, Kornmann O, Micke P, Buhl R. Glutathione deficiency of the lower respiratory tract in patients with idiopathic pulmonary fibrosis. Eur Respir J 2002; 19: 1119-1123.

182 Griese M, Ramakers J, Krasselt A, et al. Improvement of alveolar glutathione and lung function but not oxidative state in cystic fibrosis. Am J Respir Crit Care Med 2004; 169: 822-828.

183 Cereser C, Guichard J, Drai J, et al. Quantification of reduced and toal glutathione at the femtomole level by high-performance liquid chromatography with fluorescence detection: application to red blood cells and cultured fibroblast. J Chromatogr B Biomed Sci Appl 2001; 752: 123-132.

184 Kuhn KS, Krasselt AI, Furst P. Glutathione and glutathione metabolites in small tissue samples and mucosal biopsies. Clin Chem. 2000; 46: 1003-1005.

185 James SJ, Cutler P, Melnyk S, et al. Metabolic biomarkers of increased oxidative stress and impaired methylation capacity in children with autism. Am J Clin Nutr 2004; 80: 1611-1617.

186 Schleiss MB, Holz O, Behnke M, Richter K, Magnussen H, Jorres RA. The concentration of hydrogen peroxide in exhaled air depends on expiratory flow rate. Eur Respir J 2000; 16: 1115-1118.

187 Horvath I, MacNee W, Kelly FJ, et al. Haemoxygenase-1 induction and exhaled markers of oxidative stress in lung diseases. Eur Respir J 2001; 18: 420-430.

188 van Beurden WJ, Dekhuijzen PN, Smeenk FW. Exhaled biomarkers in COPD: their potential role in diagnosis, treatment and prognosis. Monaldi Arch Chest Dis 2002; 57: 258-267.

189 Broeckaert F, Arsalane K, Hermans C, et al. Serum clara cell protein: a sensitive biomarker of increased lung 
epithelium permeability caused by ambient ozone. Environ Health Perspect 200; 108: 533-537.

190 Bernard A, Crbonnelle S, Nickmilder M, de Burbure C. Non-invasive biomarkers of pulmonary damage and inflammation: application to children exposed to ozone and trichlormine. Toxicol Appl Pharmacol 2005; 206: 185-190.

191 Hermans C, Aly O, Nyberg BI, Peterson C, Bernard A. Determinants of clara cell protein (CC16) concentration in serum: a reassessment with two different immunoassays. Clin Chim Acta 1998; 272: 101-110.

192 Blomberg A, Mudway I, Svensson M, et al. Clara cell protein as a biomarker for ozone-induced lung injury in humans. Eur Respir J 2003; 22: 883-888.

193 Miwa K, Kishimoto C, Nakamura H, et al. Serum thioredoxin and $\alpha$-tocopherol concentrations in patients with major risk factors. Circ J 2005; 69: 291-294.

194 Nakamura H, Vaage J, Valen G, Padilla CA, Björnstedt M, Holmgren A. Measurements of plasma glutaredoxin and thioredoxin in healthy volunteers and during open-heart surgery. Free Radic Biol Med 1998; 24: 1176-1186.

195 Hokamaki J, Kawano H, Soejima H, et al. Plasma thioredoxin levels in patients with unstable angina. Int J Cardiol 2005; 99: 225-231.

196 Khachik F, Spangler CJ, Smith JC Jr, Canfield LM, Steck A, Pfander $\mathrm{H}$. Identification, quantification, and relative concentrations of carotenoids and their metabolites in human milk and serum. Anal Chem 1997; 69: 1873-1881.

197 Stahl W, Sies H. Uptake of lycopene and its geometrical isomers is greater from heat-processed than from unprocessed tomato juice in humans. J Nutr 1992; 122: 2161-2166.

198 Wood LG, Garg ML, Blake RJ, Garcia-Caraballo S, Gibson PG. Airway and circulating levels of carotenoids in asthma and healthy controls. J Am Coll Nutr 2005; 24: 448-455.

199 Nierenberg DW, Peng YM, Alberts DS. Methods for determination of retinoids, $\alpha$-tocopherols, and carotenoids in human serum, plasma and other tissues. In: Moon TE, Micozzi MS, eds. Nutrition and Cancer Prevention. Marcel Dekker, New York, 1989; pp. 181-209.

200 Margolis SA, Duewer DL. Measurement of ascorbic acid in human plasma and serum: stability, intralaboratory repeatability, and interlaboratory reproducibility. Clin Chem. 1996; 42: 1257-1262.

201 Alegria A, Barbera R, Clemente G, Farre R, Garcia MJ, Lagarda MJ. Selenium and glutathione peroxidase reference values in whole blood and plasma of a reference population living in Valencia, Spain. J Trace Elem Med Biol 1996; 10: 223-228.

202 Hambidge M. Biomarkers of trace mineral intake and status. J Nutr 2003; 133: Suppl. 3, 948S-955S.

203 Muñoz-Olivas R, Donard OFX, Gilon N, Potin-Gautier M. Speciation of organic selenium compounds by highperformance liquid chromatography-inductively coupled plasma mass spectrometry in natural samples. I Anal Atomic Spectr 1996; 11: 1171-1176.
204 Koyama H, Omura K, Ejima A, Kasanuma Y, Watanabe C, Satoh H. Separation of selenium-containing proteins in human and mouse plasma using tandem high-performance liquid chromatography columns coupled with inductively coupled plasma-mass spectrometry. Anal Biochem 1999; 267: 84-91.

205 Dwyer JT, Peterson JJ. Measuring flavonoid intake: need for advanced tools. Public Health Nutr 2002; 5: 925-930.

206 Radtke J, Linseisen J, Wolfram G. Fasting plasma concentrations of selected flavonoids as markers of their ordinary dietary intake. Eur J Nutr 2002; 41: 203-209.

207 Lampe JW. Isoflavonoid and lignan phytoestrogens as dietary biomarkers. J Nutr 2003; 133: Suppl. 3, 956S-964S.

208 Adlercreutz H, Fotsis T, Bannwart C, Wahala K, Brunow G, Hase T. Isotope dilution gas chromatographic-mass spectrometric method for the determination of lignans and isoflavonoids in human urine, including identification of genistein. Clin Chim Acta. 1991; 199: 263-278.

209 Franke AA, Custer LJ, Cerna CM, Narala K. Rapid HPLC analysis of dietary phytoestrogens from legumes and from human urine. Proc Soc Exp Biol Med 1995; 208: 18-26.

210 Arab L. Biomarkers of fat and fatty acid intake. J Nutr 2003; 133: Suppl. 3, 925S-932S.

211 Kohlmeier L. Future of dietary exposure assessment. Am J Clin Nutr 1995; 61: Suppl. 3, 702S-709S.

212 Bates CJ, Thurnham DI, Bringham SA, Margatts BM, Nelson M. Biochemical markers of nutrient intake. In: Margetts BM, Nelson M, eds. Design Concepts in Nutritional Epidemiology. 2nd Edn. Oxford University Press, Oxford, 1997; pp. 170-240.

213 Mason JB. Biomarkers of nutrient exposure and status in one-carbon (methyl) metabolism. J Nutr 2003; 133: Suppl. 3, 941S-947S.

214 Bagley PJ, Selhub J. Analysis of folates using combined affinity and ion-pair chromatography. Methods Enzymol 1997; 281: 16-25.

215 Duggan C, MacLeod WB, Krebs NF, et al. Plasma zinc concentrations are depressed during the acute phase response in children with falciparum malaria. J Nutr 2005; 135: 802-807.

216 Batchet L, Vaja S, Treacher D, Kinerons M, Swaminathan R. Erythrocyte zinc in hospital patients. Ann Clin Biochem 2005; 42: 448-452.

217 Torrejon CS, Castillo-Duran C, Hertrampf ED, Ruz M. Zinc and iron nutrition in Chilean children fed fortified milk provided by the Complementary National Food Program. Nutrition 2004; 20: 177-180.

218 Smith JC Jr, Butrimovitz GP, Purdy WC. Direct measurement of zinc in plasma by atomic absorption spectroscopy. Clin Chem. 1979; 25: 1487-1491.

219 Pekkanen J, Sunyer J, Chinn S. Nondifferential disease misclassification may bias incidence risk ratios away from the null. J Clin Epidemiol 2006; 59: 281-289.

220 Pekkanen J, Sunyer J, Antó JM. Operational definitions of asthma in studies on its aetiology. Eur Respir J 2005; 26: 28-35. 